NBER WORKING PAPER SERIES

\title{
IDENTIFYING INDIVIDUAL AND GROUP EFFECTS IN THE PRESENCE OF SORTING: A NEIGHBORHOOD EFFECTS APPLICATION
}

\author{
Patrick Bayer \\ Stephen L. Ross \\ Working Paper 12211 \\ http://www.nber.org/papers/w12211
NATIONAL BUREAU OF ECONOMIC RESEARCH
1050 Massachusetts Avenue
Cambridge, MA 02138

May 2006

The authors are grateful to the Department of Housing and Urban Development, Federal Reserve Bank of New York, and the Center for Real Estate and Urban Economic Studies at the University of Connecticut for financial support. We are especially thankful to Steven Durlauf for extensive comments on an earlier draft and to William Brock, Fernando Ferreira, Yannis Ioannides, Albert Saiz, Holger Sieg, Todd Sinai, and seminar participants at UC Berkeley, NYU, Penn-Wharton, and Wisconsin for many helpful comments and suggestions. The research in this paper was conducted while the authors were Special Sworn Status researchers of the U.S. Census Bureau at the Boston Research Data Center (BRDC). The research results and conclusions expressed are those of the authors and do not necessarily reflect the views of the U.S. Census Bureau, the Department of Housing and Urban Development, any other agency of the U.S. Government or the National Bureau of Economic Research. This paper was screened to insure that no confidential data are revealed.

(C) 2006 by Patrick Bayer and Stephen L. Ross. All rights reserved. Short sections of text, not to exceed two paragraphs, may be quoted without explicit permission provided that full credit, including $\odot$ notice, is given to the source. 
Identifying Individual and Group Effects in the Presence of Sorting: A Neighborhood Effects

Application

Patrick Bayer and Stephen L. Ross

NBER Working Paper No. 12211

May 2006, Revised February 2009

JEL No. J41,R14

\begin{abstract}
Researchers have long recognized that the non-random sorting of individuals into groups generates correlation between individual and group attributes that is likely to bias naïve estimates of both individual and group effects. This paper proposes a non-parametric strategy for identifying these effects in a model that allows for both individual and group unobservables, applying this strategy to the estimation of neighborhood effects on labor market outcomes. The first part of this strategy is guided by a robust feature of the equilibrium in vertical sorting models - a monotonic relationship between neighborhood housing prices and neighborhood quality. This implies that under certain conditions a non-parametric function of neighborhood housing prices serves as a suitable control function for the neighborhood unobservable in the labor market outcome regression. This control function transforms the problem to a model with one unobservable so that traditional instrumental variables solutions may be applied. In our application, we instrument for each individual's observed neighborhood attributes with the average neighborhood attributes of a set of observationally identical individuals. The neighborhood effects model is estimated using confidential microdata from the 1990 Decennial Census for the Boston MSA. The results imply that the direct effects of geographic proximity to jobs, neighborhood poverty rates, and average neighborhood education are substantially larger than the conditional correlations identified using OLS, although the net effect of neighborhood quality on labor market outcomes remains small. These findings are robust across a wide variety of specifications and robustness checks.
\end{abstract}

Patrick Bayer

Department of Economics

Duke University

213 Social Sciences

Durham, NC 27708

and NBER

patrick.bayer@duke.edu

Stephen L. Ross 


\section{Introduction}

Economists often study behavior and outcomes in empirical settings in which individuals have sorted into groups, where a group might be a school, neighborhood, occupation, interpersonal relationship, correctional or treatment program. In these settings, it is well known that sorting generates correlation between individual and group attributes (some of which are likely to be unobserved) leading to potentially serious biases in naïve estimates of the effects of individual and group attributes on individual outcomes. The resulting biases are likely to be especially severe in the estimation of social interactions (peer effects) among individuals in the same reference group, and, as a result, the identification problem created by endogenous group formation has received extensive attention in that literature (Manski (1993), Moffitt (2001), Brock and Durlauf (2001)).

In this paper, we take up the general problem of identifying the effect of individual and group attributes on individual outcomes in a model that allows for both individual and group unobservables. When both types of unobservables are present, the identification problem created by non-random sorting is especially severe because any variable that affects sorting over groups will generally, by construction, be correlated with either the individual or group unobservable (or both). As a result, many common empirical strategies that are designed to deal with the presence of one type of unobservable often neglect the presence of the other, thereby not addressing or possibly even exacerbating the corresponding biases.

To see this, consider a specific estimation technique that is used commonly in the literature: the inclusion of group fixed effects in the individual outcome regression (i.e., embedding the group unobservable in a fixed effect). While it is often argued that this approach eliminates biases resulting from across-group sorting, thereby providing unbiased estimates of the effect of observable individual attributes, this is generally not the case. The problem is that non-random sorting induces correlation between the group fixed effects and both the observed and unobserved individual attributes. In a selective hiring or matching process (e.g., teachers to schools, individuals to colleges, doctors to residency programs, individuals to occupations), one might expect, for example, higher ability students and teachers to be matched to better schools based on unobserved tastes or rationing leading to a positive correlation between school fixed effects and the individual component of the error term. ${ }^{2}$ As a result, one might expect the school fixed effects in an achievement regression estimated by OLS to be overstated and the estimated effects of observed measures of individual ability and teacher skills to be attenuated. ${ }^{3}$

That OLS estimation of a group fixed effects specification does not eliminate biases related to sorting is obvious if one considers a setting with only two potential groups. This places the problem

\footnotetext{
${ }^{2}$ In a related example, see Rothstein's (2008) analysis of bias in teacher fixed effect estimates in value added models of education production due to systematic sorting of students into classrooms.

${ }^{3}$ It is not uncommon to see group fixed effects used in estimation for environments where sorting across groups is expected. Examples include the inclusion of occupation fixed effects in wage regressions, school fixed effects in models of teacher productivity, and neighborhood fixed effects in hedonic price regressions.
} 
squarely in the treatment effects literature, where the group fixed effect becomes the treatment effect and the identification problems related to non-random selection are well known. ${ }^{4}$ Treated individuals should be similar in their actual propensity to receive treatment compared to the sample as a whole and so any within group differences in observables should be negatively correlated with unobservables. Unfortunately, most of the solutions to the identification problem created by non-random selection proposed in the treatment effects literature, such as the availability of an instrument that predicts selection into treatment but does not affect individual outcomes, do not translate easily into settings where the number of groups can number in the hundreds or thousands. ${ }^{5}$ To apply a classic instrumental variables approach in settings where the number of groups is large would require either a correspondingly large number of instruments or an instrument that varied across both individuals and groups. ${ }^{6}$

The goal of this paper is to provide a general and practical non-parametric solution to the identification problem induced by the presence of both individual and group unobservables in settings where the number of groups is large. To make the discussion of the identification problem and our proposed empirical methodology concrete, we consider a specific application: the estimation of the effect of individual and neighborhood attributes on labor market outcomes in a setting where individuals sort over the neighborhoods within a large metropolitan area. Previous strategies for identifying the effect of neighborhood on individual outcomes include examination of data arising from social experiments including the provision of housing vouchers (Popkin et al. (1993), Katz et al. (2001), Ludwig et al. (2005)) and the demolition of public housing complexes (Oreopolous (2003), Jacob (2005)), aggregating up to levels such as the metropolitan area where residence might be plausibly viewed as exogenous (Evans et al. (1992), Cutler and Glaeser (1997), Ross (1998), Weinberg (2000, 2004), Ross and Zenou (In Press), Card and Rothstein (2007), Ananat (2007)), and recently examining spatial variation in neighborhood exposure at very detailed levels of geography presumably because housing markets are quite thin at that level (Grinblatt et al. (2004), Ioannides and Zabel (2008), Bayer et al. (In Press)).

Our proposed solution to the core identification problem driven by sorting exploits a robust implication of vertical models of jurisdictional sorting like Epple and Platt (1998) and Epple and Sieg

\footnotetext{
${ }^{4}$ See, for example, Heckman (1979) and the large subsequent literature on selection.

${ }^{5}$ See, for example, Heckman and Vytlacil (2001) or Angrist, Imbens, and Rubin (1996) for a discussion of the application of instrumental variables to selection problems with few choices. Other (non-IV) solutions that have been proposed to identify models with a small number of groups (e.g., "identification at infinity" Heckman (1990)) also do not extend practically to settings with many groups because the corresponding requirements on the data (e.g., distinct values of covariates that lead to universal selection into each group) also increase proportionally with the number of groups.

${ }^{6}$ Geweke, Gowrisankaran, and Town (2003) provides a nice example of the use of an instrument that varies across both individuals and groups in a context where the number of groups is large. Specifically, they use the distance between an individual's residence and each hospital in the individual's metropolitan area to instrument for hospital indicator variables in a mortality regression.
} 
(1999), ${ }^{7}$ namely that there is a monotonic relationship between the price of group membership, in our case residing in a neighborhood, and group or neighborhood quality. Under conditions that we make explicit below, this implies that a non-parametric function of price serves as a suitable control function for the group or neighborhood unobservable in an individual outcome equation. ${ }^{8,9}$ By including this control function in the outcome regression as a proxy for the group component of the error term, ${ }^{10}$ we transform the problem into a more standard selection problem with a single individual-specific component of the error term. ${ }^{11}$ The essential advantage of this control function approach is that it reduces the dimensionality of instrumental variables problem when the number of groups is large. Now, instead of requiring as many instruments as groups, the needed number of instruments is only the number of observed group or neighborhood attributes (including the housing price control function). Instruments are required in this case to address the likely correlation of the observed neighborhood (group) attributes and the remaining individual component of the unobservable. In principle, our model might be adapted to any sorting problem where membership in the group is rationed via a market price of some sort, such as occupational choice where occupational attributes are capitalized into wages.

In the context of our neighborhood effects application, we develop instruments for neighborhood attributes by assigning each individual in the sample to a cell based on her observable characteristics. We then instrument for each individual's own neighborhood attributes with the average neighborhood attributes of those individuals in the same cell. Averaging neighborhood attributes over all observationally equivalent individuals is assumed to remove any idiosyncratic portion of the sorting of individuals into neighborhoods associated with an individual's unobservable attributes. Similar cell based identification strategies have been used as instruments in other contexts, see for example Dahl (2002) on

\footnotetext{
${ }^{7}$ This model and its predecessors has been used or extended in theoretical settings by Epple, Filimon, and Romer, (1984, 1993), Epple and Romer (1991), Epple and Romano (1999), Fernandez and Rogerson (1996, 1998) and Benabou (1993, 1996) and applied in empirical settings by Epple, Romer, and Sieg (2001), Sieg, Smith, Banzhaf, and Walsh (2004), Walsh (2005) among others. See Ross and Yinger (1999) for a review of papers that apply this sorting model within local public finance.

${ }^{8}$ Note that monotonic relationship may not hold explicitly once one allows for horizontal sorting as in the models developed by Nechyba (1997, 1999), Bayer, McMillan, and Rueben (2005), Bayer and Timmins (2005, 2006), Ferreira (2003) and Ferryera (2003).

${ }^{9}$ In addition to the residential sorting context, this solution should be applicable in any setting where the price of entry into a group is available (e.g., wages, college tuition) or where groups can be quality rank-ordered in some way.

${ }^{10}$ Petrin and Train (2005) use this strategy to control for product unobservables in the differentiated products demand literature, although it is motivated there primarily as a computational tool in a standard instrumental variables context.

${ }^{11}$ Specifically, this strategy implements the general observation made in Brock and Durlauf (2006) that a control fiunction can be used to deal with the group unobservable in an individual outcome equation. Ioannides and Zabel (2004) use such a control function in their work on housing demand. Of course, in their model, demand depends explicitly on price and a separate control function is included to break the correlation between price and unobservable determinants of demand. In relation to their work, our contribution is the specific idea to use neighborhood housing price as a control function for unobserved neighborhood quality in an individual outcome equation.
} 
the Roy model and French (2005) and French and Jones (2008) on retirement behavior. Notice also, that this approach amounts to using a fully non-parametric sorting model to predict each individual's neighborhood attributes given her observable characteristics. Brock and Durlauf $(2001,2002,2005)$ have recommended the use of such non-linearities arising from discrete choices for identification in models of social interactions. ${ }^{12,13}$

In this way, the approach that we propose for addressing the identification problem induced by non-random sorting into many groups consists of two key features: the use of a control function for the group component of the error term and the development of suitable instruments to address the remaining correlation between the individual component of the error term and any observed group characteristics (including the control function). We carefully describe the conditions under which our proposed approach provides a coherent solution to the identification problem as well as circumstances under which this approach does not work in the paper. We also include a detailed analysis of the robustness of our results to alternative assumptions in the context of our neighborhood effects application.

For our application, we use the confidential Long Form data from the 1990 Decennial Census for the Boston Metropolitan Statistical Area. In examining the impact of neighborhoods on labor market outcomes, we focus on the influence of spatial access to jobs and neighborhood socioeconomic characteristics on individual labor market outcomes. These neighborhood attributes have received a great deal of attention in the previous literature. We estimate models for six different labor market outcomes, a number of subsamples based on education, gender, and family structure, and a variety of empirical specifications designed to isolate the impact of each of the three parts of our proposed identification strategy.

Our results imply that the direct impact of geographic proximity to jobs, neighborhood poverty rates, and college-educated neighbors is substantially larger than the conditional correlations identified using OLS. These findings are robust across a wide variety of specifications and robustness checks. Interestingly, while geographic proximity and neighborhood poverty rates have the anticipated positive and negative impacts on labor market outcomes respectively, exposure to college-educated neighbors also has a significant negative effect. We discuss potential explanations for this finding below. Thus, taken together, our results imply that the relationship between neighborhood attributes and labor market outcomes is quite complex and as a whole our results are consistent with small and even negative net effects of a traditional notion of neighborhood 'quality' on the labor market outcomes.

\footnotetext{
12 Also see Bayer and Timmins (2006) and in the context of the identification of hedonic models by Ekeland, Heckman, and Nesheim (2004), Bajari and Benkhard (2005) and Bajari and Kahn (2005) and of the identification of peer effects in education by Calvo-Armengo, Patacchini and Zenou (In Press) and Patacchini and Zenou (2008).

${ }^{13}$ In addition to the two-part strategy outlined here, we also address additional issues related to neighborhood attributes endogenously determined by the sorting process (e.g., neighborhood socioeconomic characteristics) below.
} 
The remainder of the paper is organized as follows. Section 2 presents a simple vertical sorting model and examines the resulting biases in ordinary least squares analyses of the effect of individual and group attributes on individual outcomes, as well as discusses existing effects attempts to identify neighborhood effects in the context of the model. Section 3 presents our two-part estimation strategy for obtaining consistent estimates in the presence of both individual and group unobserved attributes. Section 4 reviews the literature concerning neighborhood effects on labor market outcomes, discusses the data, sample, and specification of variables used to describe households and neighborhoods, and presents the results. Section 7 concludes.

\section{Identifying Individual and Group Effects in the Presence of Sorting}

This paper posits a world where neighborhoods generate benefits for individuals that might or might not be reflected in their outcomes and individuals sort across neighborhoods trading off the benefits offered by each neighborhood against the price required for access to that neighborhood. In such a world, attributes of both individuals and neighborhoods that affect the sorting process or outcomes may be unobserved to the econometrician. Most existing research explicitly considers only an individual unobservable, only a location unobservable or does not make a clear distinction, and yet the interplay of these two unobservables is crucial in understanding the bias arising in any study of neighborhood effects.

The equation that we are interested in estimating can be written as:

$$
y_{i j}=\hat{y}_{i}+\beta_{2} X_{j}+\xi_{j}+\varepsilon_{i j}=\beta_{1} Z_{i}+\omega_{i}+\beta_{2} X_{j}+\xi_{j}+\varepsilon_{i j}
$$

where $i$ indexes individuals, $j$ indexes neighborhoods, $y_{i j}$ is the individual outcome of interest, $Z_{i}, \omega_{i}$, are observed and unobserved individual attributes respectively, and $X_{j}, \xi_{j}$ are observed and unobserved neighborhood attributes, respectively. For the purposes of developing the sorting model, we assume that $\hat{y}_{i}$ or $\beta_{1} Z_{i}+\omega_{i}$ represents an individual's permanent income and $\varepsilon_{\mathrm{ij}}$ represents short-run, transitory shocks to earnings or labor market outcomes.

Moment Conditions. At this point, we propose two apparently strong moment conditions in order to first expositionally simplify the presentation, second focus on the estimation bias caused by sorting without the additional identification issues arising from other sources of endogeneity, and finally to demonstrate the complex patterns of correlation that arise from sorting even with fairly strong moment 
conditions. Specifically, we assume that the covariances between observed and unobserved attributes are equal to zero in the distributions of individuals and neighborhoods: ${ }^{14}$

(i) $E\left[\xi_{j} \mid X_{j}\right\rfloor=0$

(ii) $E\left[\omega_{i} \mid Z_{i}\right]=0$;

A key restriction imposed by these conditions, specifically 2(i), is that the neighborhood or group variables do not include aggregations of the individual attributes for people who select into a group. Otherwise sorting based on individual observables over group unobservables would violate condition 2(i). In a neighborhood effects application, this restriction would require that variables like percent poverty or share of residents with a college education be excluded from the specification of equation (1). Therefore, it is important to note that this restriction is made only to simply the current exposition and is relaxed later in a later section.

However, throughout the paper, we will continue to assume that the only source of correlation between place observables and unobservables is the aggregation of individual attributes based on the sorting of those individuals. In effect, we are estimating reduced form estimates of the relationship between neighborhood variables and outcomes that are not biased by sorting. This assumption in Equation (2.i) simply makes explicit an assumption that is made implicitly in the vast majority of the empirical literature on peer and neighborhood effects. Even when peers or neighbors are randomly assigned, the researcher must always select a subset of potentially interesting attributes among those available in the data to include in the analysis, and. unless the research design also generates quasirandom variation in a particular peer or neighbor characteristics these attributes are bound to be correlated with the unobservables of the randomly assigned peers,

To see this point in the context of the existing peer effects literature, consider the well-known paper Sacerdote (2001). In that paper, Sacerdote uses the random assignment of roommates in the first year at Dartmouth College to test whether college GPA is affected by a roommate's prior achievement in high school. While random assignment ensures that the estimated effect is not driven by the non-random selection of one's peers, there is nothing that precludes the observed correlation of outcomes with roommate's achievement from being driven by unobservable roommate attributes, such as athletic participation or experience with drinking or drugs. Smilarly, in the neighborhood effects literature, Katz, Kling and Liebman (2001) use the randomization implicit in the Moving to Opportunity (MTO) experiment, in which residents in public housing were randomly selected to receive a housing voucher

${ }^{14}$ These assumptions of exogeneity are standard when ever an individual makes a causal interpretation of the estimated conditional correlation between an observed outcomes and control variables. While not uncontroversial, these assumptions seem reasonable in an analysis intended to examine the additional bias that might arise due to sorting. 
allowing them to move to a better neighborhood. Random assignment allows the authors to convincingly evaluate whether the receipt of the voucher altered individual outcomes. But if one is interested in assessing how exactly the program/neighborhood change affected outcomes - i.e., what it was about the change in neighborhood (or other features of the program for that matter) that caused the change in outcomes, additional assumptions like (2.i) must be made. ${ }^{15}$

Next, focusing on equation (2.ii), this assumption requires that the covariance between observed and unobserved individual attributes is zero in the population. Before discussing the particular merits of this assumption, it is important to first point out that the identification of neighborhood effects does not rely on this assumption. Our IV strategy explicitly breaks the correlation between neighborhood attributes and individual unobservables regardless of whether the individual unobservable is the unobservable associated with equation (1) or a reduced from unobservable. Thus, if we were only interested in obtaining consistent estimates of neighborhood effects - which is the central focus of our application - we could relax assumption (2.ii) and still get consistent estimates of neighborhood effects.

More generally, we are really estimating a reduced-form model of the effects of individual attributes on outcomes in our current application. For example, our estimate of the effect of individual education on outcomes would include the impact due to the correlation of education and unobserved ability purged of any bias arising from the systematic sorting of individuals into neighborhoods. Naturally if one wished to use our technique to estimate a causal effect of education on labor market outcomes, one would need to isolate quasi-random variation in educational attainment, and more importantly if such variation were available our model can be easily generalized to allow the use of such variation to identify causal impacts of individual attributes. ${ }^{16}$

Finally, in terms of the model, the important point is that even when only exogenous attributes are considered in (1), non-random sorting will generally imply correlation between all individual and neighborhood attributes, thereby creating correlation between any observed attributes and the composite error term in (1). To see why non-random sorting gives rise to such correlations, it is helpful to write down a simple modification of the vertical sorting model developed by Epple and Platt (1998) and Epple and Sieg (1999).

\footnotetext{
${ }^{15}$ This can be seen clearly in a follow-on paper on MTO by Kling and Ludwig (2007). In that paper, they test whether the neighborhood crime rate affects individual criminal activity. Naturally, the neighborhood crime rate may be correlated with a wide variety of other neighborhood characteristics, which is why the researchers include other control variables such as share minority and poverty rate, but such controls only represent a fraction of the neighborhood variables with which crime rates may correlate.

${ }^{16}$ In the context of the Census, there is a variable that many authors have used to instrument for education -- the timing of birth within a year (i.e., exact birth date). Therefore, if we were interested in obtaining a causal estimate of the effect of education on labor market outcomes, we could in fact use the timing of birth as an instrument. The resulting coefficient estimate would control for both the self-selection of additional years of schooling plus the effect of neighborhood sorting.
} 
A Simple Model of Residential Sorting. Consider a closed metropolitan area consisting of $J$ neighborhoods with a finite number of houses available in each neighborhood. Exogenous neighborhood attributes $X_{j}$ and $\xi_{j}$ are distributed such that (2.i) holds. The population of the metro area consists of $I$ individuals, which is also assumed to equal the total number of houses available in the metropolitan area. Individual $i$ has individual characteristics $Z_{i}$ and $\omega_{i}$ distributed such that (2.ii) holds.

Given the structure of equation (1), it will be helpful to characterize the neighborhood contribution to the individual outcome $y$ as:

$$
\theta_{j}=\beta_{2} X_{j}+\xi_{j}
$$

It is this neighborhood quality index $\theta_{j}$ for which individuals will implicitly be willing to pay a higher price of entry $p_{j}$ to enter a given neighborhood $j .{ }^{17}$

Individuals sort across neighborhoods based on their permanent income trading off between the outcome of interest $\theta_{j}$, which may affect both earnings and other intangible benefits of residing in a neighborhood, and the price of purchasing housing in neighborhood $j, p_{j}$. Specifically, write individual utility $V$ from choosing neighborhood $j$ as a function of expected income, the neighborhood quality index, and the price of housing:

$$
V_{i j}=V\left(\hat{y}_{i}+\theta_{j}, \theta_{j}, p_{j} \mid \hat{y}_{i}\right)=f\left(\hat{y}_{i}, \theta_{j}, p_{j}\right)
$$

where an individual's taste for the non-labor market benefits offered by the neighborhood quality index may vary with permanent income. ${ }^{18}$

Structure of Equilibrium. Decisions in the model are driven by the trade-off between neighborhood quality and neighborhood housing prices, $p$. In equilibrium, the price of entry into each neighborhood adjusts so as to ration the quality of the neighborhood good $\theta_{j}$ available there. To derive predictions about the structure of the equilibrium, it is helpful to make the following single-crossing property on preferences:

\footnotetext{
${ }^{17}$ In Section 4 below, we consider generalizations of this simple sorting model to cases where individuals value more about neighborhoods than the direct effect of neighborhood on income or earnings.

${ }^{18}$ The model could readily be generalized to allow for a separate individual-specific taste parameter. This extension would yield very similar results as long as permanent income and the taste parameter are positively correlated as is typically presumed in the literature on neighborhood effects.
} 
(5) $\frac{d^{2} p}{d \theta d \hat{y}}>0$

This single-crossing property implies that as an individual's permanent income increases, the slope of the indifference curve between the price of entry into the neighborhood $p$ and the consumption of the neighborhood good $\theta$ decreases, ceteris paribus.

Figure 1: Stratification of Individuals Across Neighborhoods in Equilibrium

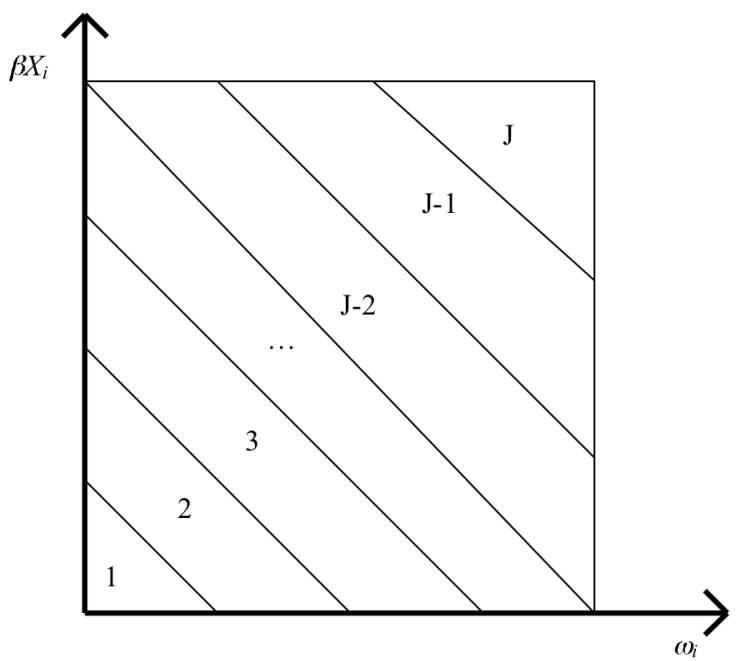

Given this single-crossing assumption, a sorting equilibrium exists and satisfies a number of useful properties (Epple and Platt, 1998). ${ }^{19}$ Figure 1 provides a graphical depiction of the equilibrium, showing how individuals sort themselves across neighborhoods with increasing values of the neighborhood good $\theta_{J}>\theta_{J-1}>\ldots>\theta_{2}>\theta_{1}$. The vertical axis indicates an individual's observable permanent income $\beta X_{i}$, while the horizontal axis depicts unobserved permanent income $\omega_{i}$. The diagonal lines in the figure characterize the boundaries in $\left(\beta X_{i}\right)-\omega_{i}$ space that divide the set of individuals that choose one neighborhood versus another. ${ }^{20}$ For expositional purposes, the graph is drawn assuming a

\footnotetext{
${ }^{19}$ This single crossing condition implies that single crossing conditions hold for $\left(\beta X_{i}\right)$ and $\omega_{i}$, which are equivalent to the two single crossing conditions in Epple and Platt (1998).

20 The additive relationship between $\left(\beta X_{i}\right)$ and $\omega_{i}$ assures that these boundary indifference curves are straight, parallel lines, but in more general models these lines may not be either straight or parallel.
} 
finite support for both observable and unobservable components of permanent income although this is not required.

A key property of the equilibrium is that individuals are conditionally stratified across neighborhoods. That is, conditional on the observable component of permanent income $\left(\beta X_{i}\right)$, individuals are stratified across neighborhoods on the basis of the unobserved component $\omega_{i}$ and vice versa. The first of these results can be seen in Figure 1 by considering individuals with a given value of the observed permanent income $\left(\beta X_{i}\right)$ and moving horizontally across neighborhoods. In this case, any individual $\mathrm{A}$ with unobservable permanent income greater than individual B chooses a neighborhood with at least as great a value of $\theta$. Likewise, the second stratification result can be seen by conditioning on unobservable permanent income and moving vertically across neighborhoods.

Implications of Equilibrium Structure for Estimating the Outcome Equation. When combined with the exogeneity assumptions in (2), these stratification results give rise to a number of additional properties of the sorting equilibrium that are relevant for the estimation of equation (1).

Most obviously, the model ensures permanent income (observed and unobserved components) and neighborhood quality (observed and unobserved components) are positively correlated. From the point of view of estimating equation (1), the implication is that sorting induces a positive correlation between the unobserved neighborhood quality and the observed component of permanent income:

$$
\operatorname{Cov}\left\lfloor\hat{\underline{y}}_{i} \theta_{j} \mid X_{j}, \omega_{i}\right\rfloor E\left[\left(\beta_{1} Z_{i}^{\prime}\right) \xi_{j} \mid X_{j}, \omega_{i}\right\rfloor 0 \text {; }
$$

and likewise between individual error term and observed neighborhood quality:

$$
\operatorname{Cov}\left\lfloor\hat{y}_{i}, \theta_{j} \mid Z_{i}, \xi_{j}\right\rfloor E\left[\left(\beta_{2} X_{j}^{\prime}\right) \omega_{i} \mid Z_{i}, \xi_{j}\right\rfloor 0 ;
$$

These correlations imply that OLS estimates of the coefficients in equation (1) will generally be biased.

A second less obvious property that follows from the model is that conditional on neighborhood, observable and unobservable components of permanent income are negatively correlated:

$$
\operatorname{Cov}\left[\left(\beta^{\prime} X_{i}\right), \omega_{i} \mid j_{i}\right]=E\left[\left(\beta^{\prime} X_{i}\right) \omega_{i} \mid j_{i}\right]<0
$$

This property follows directly from the fact that $\left(\beta X_{i}\right)$ and $\omega_{i}$ are uncorrelated in the population and the stratification properties mentioned above, which ensure that the boundaries between neighborhoods in $\left(\beta X_{i}\right)-\omega_{i}$ space are downward sloping. Given this negative within neighborhood correlation, it is easy to 
see that including neighborhood fixed effects when estimating equation (1) via OLS does not solve the problem. In the simple model specified here, it is easy to see that such an approach would bias the coefficients on observed individual attributes towards zero. For example, Fu and Ross (2007) find that the inclusion of Public Use Microdata Area fixed effects, which are large, heterogenous areas containing 100,000 or more individuals, attenuates estimates on education variables in wage equations by over 10 percent and leads to a 50 percent or more increase in estimated agglomeration economies due to sorting on unobserved productivity attributes.

Identifying Neighborhood Effects Models. Because sorting induces the rich pattern of correlation between observables and unobservables shown in equations (6.i), (6.ii), and (7), the identification of individual and neighborhood (group) effects in equation (1) is a fundamentally difficult problem. In this paper, we seek to provide a general solution to this identification problem in the context of a fullyspecified model of sorting and outcomes. To put our proposed solution in context, we now present a brief review of other recent approaches to identifying neighborhood effects, noting their strengths and limitations. We defer a detailed review of the previous literature on the effect of neighborhood on labor market outcomes until Section 4 of the paper.

The identification of neighborhood effects is a difficult problem without a completely general solution. An important line of recent research seeks to identify neighborhood effects by isolating a random component of neighborhood choice induced by special social experiments. Popkin et al. (1993) pioneered this approach using data from the Gautreaux Program conducted in Chicago in the late 1970's, which gave housing vouchers to eligible black families in public housing as part of a court-imposed public housing de-segregation effort. Similarly, Oreopolous (2003) and Jacob (2005) study the impact of re-locations arising from administrative assignment to public housing projects in Toronto and from the demolition of the public housing projects in Chicago, respectively. Most notably, Katz et. al. (2001) and Ludwig et al. (2005) have used the randomized housing voucher allocation associated with the Moving To Opportunity demonstration (MTO) to examine the impact of re-location to neighborhoods with much lower poverty rates on a very wide set of individual behavioral outcomes including health, labor market activity, crime, education, and more. Especially in the case of MTO, the advantages of this approach are clear - the randomization inherent in the program design ensures a clean comparison of treatment and proper control groups.

There are, however, important limitations in the extent to which the treatment effects identified through re-location are informative about the nature of general forms of neighborhood effects per se. First, individuals studied must be eligible for a re-location program in the first place; this typically implies that the resulting sample is special (i.e. so as to be a resident in public housing) and may not be as sensitive to neighborhood effects as other individuals (Weinberg, 2005). Second, the experimental design 
involves re-location to new neighborhoods that are, by design, very different from baseline neighborhoods; this implies that the identified treatment effect measures the impact of re-locating to a neighborhood where individuals initially have few social contacts and where the individuals studied may be very different than the average resident of the new neighborhood. In this way, the treatment effects identified with this design are necessarily a composite of several factors related to significant changes in neighborhoods that are not easily disentangled (see Moffitt (2001) for a detailed discussion).

A second broad approach seeks to deal with the difficulties induced by correlation in unobserved attributes at the neighborhood level by aggregating to a higher level of geography. Evans, Oates, and Schwab (1992), Cutler and Glaeser (1997), Ross (1998), Weinberg (2000, 2004), Ross and Zenou (In Press), Card and Rothstein (2007), and Ananat (2007) identify the effect of location on outcomes using cross-metropolitan variation. For example, Cutler and Glaeser (1997) analyze the impact of segregation within a metropolitan area on a variety of outcomes including education, labor market activity, and teenage fertility, and Evans, Oates and Schwab use metropolitan area poverty rates as an instrument for neighborhood level poverty. Again, the advantages of this approach are clear - aggregation certainly eliminates the problem of correlation in unobservables among neighbors (although potential correlation in unobservables at the metropolitan level becomes an issue). The effects identified through aggregation, however, include not only the average neighborhood effects operating in a metropolitan area but also any broader consequences of living in a segregated or high poverty metropolitan area. ${ }^{21}$ Thus, the strict interpretation of the estimated effects as neighborhood effects requires the assumption that metropolitan segregation does not directly affect outcomes. ${ }^{22}$

A third approach examines the impact of immediate neighbors on an indiviual's outcomes after controlling for this individual's presence in a broader neighborhood (Grinblatt et al. (2004), Ioannides and Zabel (2008), Bayer et al. (2008)). The key identifying assumption underlying this design is that there is no correlation in unobserved individual attributes across nearby neighbors, due perhaps to the thinness of the housing market (i.e., that it is difficult to select the particular block that one would like to live on) after controlling for the propensity to reside in a given neighborhood. For example, Bayer, Ross, and Topa (In Press) use detailed Census microdata to compare the propensity of individuals who reside on the same census block to work together relative to the likelihood of working together for individual residing in nearby blocks or in the same block group. ${ }^{23}$ Accordingly, the methodology is designed to capture very

\footnotetext{
${ }^{21}$ More residentially segregated metropolitan areas might be associated, for example, with increased racial tastebased discrimination in the labor market, in the application of criminal justice, etc. due to decreased levels of regular inter-racial contact in residential neighborhoods.

${ }^{22}$ It is important to point out that Cutler and Glaeser (1997) do not claim that the effects identified in their analysis are strictly neighborhood effects.

${ }^{23}$ Bayer et. al. (In Press) explicitly emphasizes this variation as the source of variation, but Grinblatt et al. (2004) and Ioannides and Zabel (2008 both rely on similar variation with Grinblatt et al. examining the influence of car consumption of an individual's closest 10 neighbors conditioning on the car consumption of the next 40 neighbors
} 
local social interactions that might significantly affect outcomes (e.g., through job referrals) but whose influence decays very quickly with distance. This approach will not capture effects that arise over broader areas, such as the influence of employment access, crime, institution based networks such as schools and churches, or spatially based perceptions of economic opportunities on employment outcomes. As a result, such studies may substantially understate the impact of neighborhood social interactions on individuals' outcomes.

The vertical sorting model that we described above provides a useful framework for understanding the existing literature. The key feature of the model is that it contains two sources of error over which individuals sort, both individual- and neighborhood-specific components. In this context, the requirements for a proper instrument for either the observed individual or neighborhood attributes are severe. An instrument for a given neighborhood attribute must be correlated this neighborhood attribute and yet be uncorrelated with both the individual and neighborhood unobservable. These three requirements generally cannot hold simultaneously in observational data from a sorting equilibrium as any variable that is uncorrelated with the individual unobservable will only be correlated with neighborhood choice by affecting sorting over both observed and unobserved location attributes. ${ }^{24}$

In light of this general problem, the existing studies discussed above develop empirical designs intended to provide a variable that is correlated with an individual's exposure to location attributes for reasons that are independent of the individual's sorting behavior (experimental treatment, exogenous residence in metropolitan areas, or random block-level sorting arising from a thin housing market). Simply put, these approaches attempt to isolate variation in local attributes that arises due to factors outside the individual's control.

But these designs in turn limit the researchers' ability to isolate and identify the effects of various neighborhood factors on current residents. By systematically addressing the sources of sorting bias in a population of current neighborhood residents, the goal of this paper is to provide a more detailed and complete picture of the influence neighborhood on resident outcomes albeit with newly imposed assumptions concerning the structure of the underlying sorting problem. Specifically, unlike most of the studies above, this study is intended to capture the overall effect of neighborhood variables on a representative population in their equilibrium locations. Moreover, our approach generates a substantial amount of identifying information for relatively large population-based samples. Therefore, unlike the studies above that rely on across-metropolitan variation or small experimental samples and so are only

and Ioannides and Zabel estimating a selection model at the census tract level and identifying the impact of an individual's 10 closest neighbors' housing consumption based on the tract selection model and the attributes of those 10 closest neighbors.

${ }^{24}$ Likewise, any variable that is uncorrelated with the neighborhood unobservable can only be correlated with neighborhood observables if it is correlated with individual unobservables that influence sorting. 
able to examine one or two variables of interest, our study is able to examine the effect of a larger variety of neighborhood variables on individual outcomes.

\section{Proposed Solution}

Given the complex correlation patterns between the observed and unobserved components of equation (1), we propose a two-part estimation strategy. The core identification problem is that multiple unobserved factors can explain the same observed individual location decisions. For example, an individual that has observable characteristics that would normally be associated with high permanent income might reside in a neighborhood that looks to be low quality on the basis of observables either because (i) the neighborhood has unobserved features that are very attractive or (ii) the individual's actual permanent income is much lower than what the individual's observable attributes would suggest.

The key insight that we draw from the sorting model is that this apparent ambiguity can be resolved by using information on neighborhood housing prices. If the neighborhood in question has high housing prices, the natural conclusion is that neighborhood is attractive for unobserved reasons, but if prices are low the only way to explain the observed locational choice is through the individual's unobservable. In this way, our strategy is to use a flexible function of housing prices as a proxy for the unobserved portion of neighborhood quality in (1). This reduces the problem to a more traditional selection problem based on individual unobservables, which we address using a standard instrumental variable technique to break the correlation between neighborhood attributes and individual unobservables. $^{25}$

In this section we provide the details of this estimation strategy for our particular application. We then extend the analysis to allow for endogenous neighborhood attributes such as the socioeconomic characteristics of one's neighbors. Finally, we conclude this section by considering generalizations of the simple sorting model presented above and discussing the extent to which the estimation strategy can be extended in those circumstances.

General Treatment of Price as a Control Function . To illustrate this two-part solution, we begin by considering the problem described in condition (6.i) above: the correlation of observable individual attributes with unobserved neighborhood attributes. In this case, it turns out that a second property of the sorting equilibrium suggests a natural fix. In particular, Epple and Platt (1998) prove that neighborhoods

\footnotetext{
${ }^{25}$ This solution requires that the supply elasticity of group openings be constant across groups. In the neighborhood effects model, the supply elasticity of housing must be constant across neighborhoods, which suggests that price might not be a suitable control function for an analysis including exurban and rural areas with high elasticities of supply. In our application, we focus on the Boston Metropolitan Statistical Area, which is heavily developed with little opportunity for the construction of new housing.
} 
with increasing values of $\theta_{J}>\theta_{J-1}>\ldots>\theta_{2}>\theta_{1}$ are also ordered monotonically in terms of neighborhood housing prices: $p_{J}>p_{J-1}>\ldots>p_{2}>p_{I}$.

This monotonicity condition implies that there exists a function $f$ such that $\theta=f(p)$. Thus, a nonparametric function of neighborhood housing prices can serve as a perfect control function for $\theta$ in equation (1):

$$
y_{i j}=\beta_{1} Z_{i}+f\left(p_{j}\right)+\omega_{i}+\varepsilon_{i j}
$$

Given a consistent estimate of $f(p)$ and the additive separability assumptions of the labor market model in equation (1), $\beta_{2}$ can then be recovered from a simple regression of $f(p)$ on $X$ :

$$
\hat{f}\left(p_{j}\right)=\beta_{2} X_{j}+\xi_{j}
$$

A difficulty remains, however, if equation (8) were estimated via OLS: namely the correlation of $f\left(p_{j}\right)$ with $\omega_{i}$. The remaining correlation between the observed and unobserved portion of equation (8) is due directly to the stratification result in the sorting model: simply put, individuals with high permanent income have a strong taste for the outcome of interest and choose higher quality neighborhoods and, as a result, the direct effect of unobservable individual attributes bias the estimation of equation (8). But this correlation leads to a standard endogeneity bias that can be addressed by finding an instrument that is correlated with the price of an individual's neighborhood but not with the individual's unobserved attribute. In the next section, we describe our proposed solution to this problem for our particular application. The key insight to take away from the analysis of the sorting equilibrium is that prices can serve as a control function for the neighborhood component of the unobservable in the outcome equation (1), thereby reducing the identification to the more manageable one of dealing with a single unobservable.

Implementing the Control Function. In practice, we make two key modifications when including a control function in equation (9). First, we include a linear function of housing price rather than a nonlinear function. This simplification has the advantage of placing the estimations for our example into the relatively straightforward world of two-stage least squares rather than considering estimation of nonparametric instrumental variables models.

Second, instead of generating a control function for the full neighborhood quality index $\theta$, we instead focus on developing a control function for just the unobservable, leaving $\beta_{2} X_{j}$ in the main estimating equation. This relaxes the vertical assumption that is imposed by our model in that preferences need only be homogeneous over the neighborhood unobservable not for neighborhood quality overall. 
Specifically, we estimate a control function for $\xi_{j}$ as the average residual for each neighborhood arising from a simple housing price equation estimated for the entire metropolitan area, see also Seig, Smith, Banzhaf, and Walsh (2002). The housing price $\left(p_{i j}\right)$ can be described by

$$
p_{i j}=\delta_{1} W_{i j}+\delta_{2} X_{j}+\lambda_{j}+u_{i j}
$$

where $W_{i j}$ is a vector of housing unit attributes. Controlling for housing characteristics absorbs out any aspect of prices that are explained by housing attributes. We do this because we think housing attributes are a dimension of prices that are unlikely to contribute directly to labor market outcomes. We then estimate:

$$
y_{i j}=\beta_{1} Z_{i}+\beta_{2} X_{j}+\beta_{3} \hat{\lambda}_{j}+\omega_{i}+\varepsilon_{i j}
$$

where we must deal directly with the correlation of $X_{j}$ and $\hat{\lambda}_{j}$ with $\omega_{i}{ }^{26}$

Instrumenting for Neighborhood Attributes. To address this correlation we want to instrument for $X_{j}$ and $\lambda_{j}$ with a portion of observed neighborhood attributes that are uncorrelated with an individual's own unobserved attribute. We propose to use a function of the average values of observed neighborhood prices for families with the same observable characteristics $Z_{i}$ as instruments: $E\left[X_{j}, \hat{\lambda} \mid Z\right]$. The logic behind these instruments is that (i) the instruments should be predictive of location because similar individuals should make very similar location choices if they face the same opportunity set (metropolitan housing market), and (ii) the instruments should not be correlated with the individual's unobservable because they are based entirely on individual observables that have already been included directly in the labor market equation. $^{27}$

Most individual and family attributes, such as parent's education, or family size, are discrete in nature. For the purpose of developing these instruments, we organize individuals into homogenous cells based on all possible permutations of the discrete observable attributes that explain an individual's outcomes in the labor market. Specifically, the mean neighborhood exposure within an individual's cell

\footnotetext{
${ }^{26}$ As in equation (11), the neighborhood attributes including unobserved neighborhood attributes are assumed to enter the housing price equation (10) in an additively separable manner. This simplification yields tractable estimation equations and assures that our empirical results are driven strictly by our exclusion restrictions rather than any specific functional form assumptions.

${ }^{27}$ In principle, one might imagine that individuals in the same cell are similar on unobserved features, such as ability or tastes, so that the cell members location choices are driven by unobservables that are similar to the unobservables that drive the individual's location choice. This possibility is ruled out, however, by the assumption in equation (2) that individual observables are uncorrelated with individual unobservables.
} 
is used to instrument for the individual's actual exposure to various neighborhood attributes. The reader should note that an individual's actual location attributes are always excluded from the calculation of the cell exposure rates applied to a specific individual. ${ }^{28}$ Dahl (2002) develops instruments using a similar approach based on state of birth and individual attributes for estimating a Roy model, and recent dynamic programming applications (Gourinchas and Parker (2002), French (2005), French and Jones (2008)) use very similar sets of instruments. In practice, these cell means are quite predictive of the attributes of an individual's actual neighborhood suggesting that are instruments have sufficient power.

A couple of additional features about this instrument are worth noting. First, notice that $E\left[X_{j}, \hat{\lambda} \mid Z\right]$ are essentially nonparametric predictions of the observed and unobserved quality of neighborhood that an individual with a particular set of characteristics $\mathrm{Z}$ would choose. In this way, our IV approach amounts to using a fully non-parametric sorting model to predict each individual's neighborhood attributes given her observable characteristics. This empirical strategy exploits the nonlinearities inherent in the sorting process. That such non-linearities could serve as the basis for identification of individual outcome equations in the presence of sorting has been key insight of the work by Brock and Durlauf $(2001,2002,2005)$ and has been exploited in closely related work by Bayer and Timmins (2006). Ekeland, Heckman, and Nesheim (2004), Bajari and Benkhard (2005) and Bajari and Kahn (2005) use similar sources of identification in the estimation of hedonic models.

Second, notice that in a single metropolitan housing market this expectation relies on nonlinearities. If $\mathrm{Z}$ were allowed to enter (1) completely flexibly, the instrument would contain no independent variation. In the application that follows, which is based on data from a single large metropolitan area, the independent variation in our instrument derives from the fact that we simultaneously use multiple household characteristics to define the cells upon which our instruments are based. At the same time, we include each type of characteristic (e.g., education, household structure) only directly in the outcome equation (1). The effect of neighborhood would be unidentified if the outcome model included a fixed effect for each of cell of observationally equivalent individuals. It is important to point, however, that the method that we propose here could easily be extended to multiple metropolitan areas. In that case, even if fixed effects were included directly in (1) for each household category upon which the instrument was based, the instrument would have independent variation due to variation in average location decisions made by identical household types in different metropolitan markets. ${ }^{29}$

\footnotetext{
${ }^{28}$ One might worry that we include individuals residing in the same neighborhood as the individual when calculating the predicted neighborhood attributes to use as instruments. In fact, the opposite is true excluding such individuals would create a negative correlation between the instrument and the individual's unobservables that determine neighborhood choice.

${ }^{29}$ For an example, see Ross and Zenou (In Press).
} 
Allowing for Endogenous Neighborhood Attributes. A final endogeneity issue arises in our application because some of the neighborhood attributes that we would like to consider are endogenously determined by the sorting process itself. Specifically, in our baseline specifications, we include measures of the average educational attainment and percent of households in poverty within the neighborhood in equation (1). Re-writing equation (10) and (11) here to explicitly include neighborhood averages of certain individual attributes $\bar{Z}_{j}$ gives:

$$
\begin{aligned}
& p_{i j}=\delta_{1} W_{i j}+\delta_{2} X_{j}+\delta_{3} \bar{Z}_{j}+\lambda_{j}+u_{i j} \\
& y_{i j}=\beta_{1} Z_{i}+\beta_{2} X_{j}+\beta_{3} \bar{Z}_{j}+\beta_{4} \hat{\lambda}_{j}+\omega_{i}+\varepsilon_{i j}
\end{aligned}
$$

Since the sorting process generates a correlation between $Z_{i}$ and $\xi_{j}$ it follows immediately that $\bar{Z}_{j}$ and $\xi_{j}$ will be correlated in an analogous way in equation (12). To estimate equation (12) therefore, we develop instruments for neighborhood demographic variables using the composition of neighborhoods with similar fixed or exogenous attributes, such as the employment access of the location or the physical quality of the housing stock in the neighborhood. Since neighborhood attributes tend to be continuous variables, a distance measure is developed to characterize the degree of similarity between neighborhoods. The instruments for each $\bar{Z}_{j m}$ are a weighted average of the $\bar{Z}_{k m}$ 's for neighborhoods that are similar to neighborhood $j$ with the weight based on the degree of similarity or proximity (inverse of the distance in attribute space). Specifically,

$$
\widehat{Z}_{j}=\operatorname{Mean}_{k \in \Pi_{-j m}}\left(\bar{Z}_{k} W\left(X_{j}, X_{k}\right)\right)
$$

where $W$ represents a weighting function based on a non-parametric kernel smoother, such as the tri-cubic kernel where $W\left(X_{j}, X_{k}\right)=\left(1-\left(D\left(X_{j}, X_{k}\right) / D_{\text {Max }}\right)^{3}\right)^{3}, D$ is a distance function, and $D_{\max }$ is the maximum distance over which neighborhoods will be considered, see McMillen (1996). The instrument is exogenous to $\bar{Z}_{j}$ given the exogeneity of $X_{j .}{ }^{3031}$

\footnotetext{
${ }^{30}$ The cubic spline requires the specification of a maximum distance at which all locations beyond that distance have zero weight. This distance was chosen for each block group so that ten percent of all block groups are used to calculate the average for a given block group. Results are very similar using twenty or five percent of all block groups. Naturally, the block group itself is not included in this weighted average.

${ }^{31}$ Again, as in the use of aggregation to form instruments for the earlier part of our estimation strategy, the use of aggregation in a single metropolitan housing market again implies here that the independent variation in our
} 
Having estimated equation (12), we then estimate equation (13) using the same strategy outlined in the previous sub-section, forming instruments based on average neighborhood attributes for households in the same cell for both exogenous and endogenous neighborhood attributes.

Generalizing Our Simple Sorting Model. A key assumption underlying the simple sorting model that we outlined in Section 3 is that individuals are 1. homogeneous in their preferences for neighborhood quality after conditioning on permanent income and 2. neighborhood quality can be characterized by a single dimension that affects both labor market outcomes and the utility derived from residing in the neighborhood in the same way.

Relaxing the first assumption creates a situation where individuals will sort across communities based on their preferences. Certainly, if individuals sort over preferences for neighborhood quality, the observable portion of permanent income, and the unobservable portion of permanent income, a more complex sorting pattern will emerge. However, as long as preferences are positively correlated with permanent income, sorting over communities based on preferences will simply reinforce the implications of sorting over communities based solely on permanent income.

The second assumption is crucial since it is for this reason that a flexible function of neighborhood housing prices makes a perfect control function for $\theta$, the neighborhood contribution to the production of $y$. To the extent that households instead value multiple dimensions of neighborhood quality, a flexible function of neighborhood housing prices will no longer serve as a perfect control function for $\theta$.

So, how severe of a problem is this second assumption for our proposed methodology? The first thing to note is that if other dimensions of neighborhood quality that affect household consumption are observable, they can be first conditioned out of neighborhood housing prices in a first stage hedonic price regression. ${ }^{32}$ This is the reason, for example, that we condition on housing attributes in estimating equations (10) and (11) and separately estimate the effect of observed neighborhood attributes on labor market outcomes. In our application, the model need only be one-dimensional in the unobserved neighborhood attributes. ${ }^{33}$ If, on the other hand, households value another dimension of neighborhood quality that is unobserved, the control function approach that we propose will no longer work perfectly. In that case, our proposed method will work only as well as housing prices are indeed correlated with that

\footnotetext{
instrument derives from nonlinearities. It is again important to point, however, that the method that we propose here could easily be extended to multiple metropolitan areas, where again independent variation in the instrument would arise naturally due to across market variation. See the Identification sub-section below for more discussion of this point.

${ }^{32}$ If these other neighborhood attributes are exogenous, this first stage regression can be estimated via OLS. If they are endogenous, instruments would need to be used in the first-stage regression analogous to those discussed in the previous sub-section of the paper.

${ }_{33}$ If the theoretical model were to hold over all attributes, observable and unobservable, the coefficients in the price and outcome equations must be same, at least within a scalar multiple.
} 
aspect of neighborhood quality that affects the outcomes of interest. In our application, we seek to control directly for a wide enough set of variables that affect housing prices but not labor market outcomes (e.g., housing attributes) in the estimation of the first-stage hedonic price regression so that this issue is not first-order.

Robustness and Identification. It is important that the reader be aware of the strengths and limitations of this identification strategy. The instruments used for neighborhood contribution in both the labor market outcome and housing price/rent models make intuitive sense. In the individual sample, the exposure of observationally equivalent individuals are used to instrument for the individual's exposure to specific neighborhood attributes, and similarly the demographic composition of neighborhoods with observationally similar environmental variables, primarily housing stock composition, is used to instrument for a neighborhood's demographic composition in the sample of housing units. Since these instruments are based on observable characteristics of individuals and neighborhoods, they should be orthogonal to individual and neighborhood unobservables, respectively.

As discussed earlier, the instruments exploit the highly non-linear relationship that is likely to arise between observable attributes and sorting outcomes. The models are identified because some nonlinear terms are excluded from the second stage labor market and housing price regressions. We attempt to address concerns with this identification strategy in a number of ways. First, the labor market models are expanded to include important non-linearities, e.g., the interaction of gender with family structure. Further, we rerun the analyses dropping individuals with high levels of human capital with the expectation that these individuals benefit less from neighborhood level information on the labor market. Both of these changes substantially modify the variation in the data that indentifies the estimated coefficients for neighborhood variables, and we would expect the results to be unstable and move in unexpected directions in response to these changes. Similarly, we conduct additional analyses that control for the actual neighborhood housing stock composition in the housing price and labor market equations. As above, we would expect spurious estimates to be quite sensitive to including such variables, which are likely to soak up a substantial amount of information associated with neighborhood unobservables. These tests are analogous to standard overidentification tests. ${ }^{34}$

We also posit that the influence of neighborhood on household capital income is likely to be much smaller than the neighborhood effect on labor market outcomes. We regress outcomes concerning capital income on the same set of individual and neighborhood variables using both ordinary least squares

\footnotetext{
34 Overidentification tests implicitly test whether models based on subsets of exclusion restrictions can be distinguished statistically from a model that uses all exclusion restrictions. If so, one or more of the identifying restrictions represent misspecifications of the second stage model. In our case, we are eliminating exclusion restrictions by including more information in the model, as well as by dropping sets of observations that provide additional identifying information in order to test whether the empirical estimates are robust.
} 
and our instrumental variables specification. If our identification strategy is valid, we would expect that neighborhood variables exhibit a high correlation with capital income using OLS models due to sorting, but much smaller effects using our IV specification.

Finally, the reader should be aware of the implications of the key exogeneity assumptions made in equation (2). The exogeneity assumption for individual variables $Z_{i}$ is fairly straight forward and well understood in the literature. The impact of an individual variable like education level is likely to capture the influence of both education and any individual unobserved attributes, such as motivation, that are correlated with education. The exogeneity assumption for neighborhood variables is similar for a variable that is considered fixed $X_{j}$. For example, good job access may be correlated with some negative aspects of neighborhood quality, and therefore capture both positive effect of job access and the ambiguous effect of the portion of unobserved neighborhood quality that is correlated with job access in the population of neighborhoods.

\section{An Empirical Example: The Effect of Neighborhood on Labor Market Outcomes.}

Before presenting the results of our analysis, we begin with a brief summary of the results of previous studies have examined the relationship between neighborhood environment and employment outcomes. This summary serves the dual purposes of putting our own results in context and helping to explain our choice of the variables on which we focus describing our results.

The spatial mismatch hypothesis, first proposed by Kain (1968), has spawned innumerable studies that find that job access is positively correlated with employment and/or labor market earnings. Ihlanfeldt and Sjoquist (1990) and Raphael (1998), for example, find that youth residing far from suburban areas where low skill jobs tend to be locatedand where new jobs tend to be created had worse employment outcomes. Other research has centered on the impact of the characteristics and behavior of neighbors on labor market outcomes. Case and Katz (1991), for example, find a correlation between youth idleness and the idleness of neighbors, while O'Regan and Quigley (1998) find that youth are more likely to be high school dropouts and unemployed when they reside in high poverty neighborhoods. Weinberg, Reagan and Yankow (2004) find that people who move to neighborhoods with worse attributes have worse employment outcomes, and Ioannides and Zanella (2008) find that movers choices are consistent with neighborhoods having an impact children's outcomes ${ }^{35}$

Many scholars have suggested job market referrals or information networks as an important factor behind such neighborhood effects. ${ }^{36}$ Rees and Schultz (1970), Corcoran et al. (1980), Holzer

\footnotetext{
35 These papers represent a small sample of very large literatures. For broader surveys of these literatures, see Durlauf (2004), Ihlanfeldt and Sjoquist (1998), Ellen and Turner (1997), and Mayer (1996)

36 The use of informal channels such as referrals by employers can be rationalized as a means to reduce the uncertainty regarding the quality of a prospective employee. Montgomery (1991) was the first to formally model a labor market in which both formal and informal hiring channels coexist. Focusing more closely on the information
} 
(1988), Blau and Robbins (1990), Blau (1992), Granovetter (1995), Addison and Portugal (2001) and Wahba and Zenou (2003) all document the importance of referrals and other informal hiring channels in the labor market, using both U.S. and non-U.S. data. A number of these studies including Holzer (1988) and Blau and Robbins (1990) find that informal referrals are more productive than more formal methods in terms of job offer and acceptance probabilities. Additional studies including Datcher (1983), Devine and Kiefer (1991), Marmaros and Sacerdote (2002), and Loury (2004) find evidence that use of informal networks increases the quality of the match as captured by job tenure or earnings. ${ }^{37}$

Further, this literature suggests that the effect of referrals varies considerably across different demographic groups. In terms of intensity of usage, workers with less education and located in high poverty rate neighborhoods are more likely to use informal contacts (Elliot, 1999), men use referral networks more intensively than women (Corcoran et al., 1980), and Hispanic men use networks more intensively than non-Hispanic white men (Smith, 2000). The productivity of networks also appear to differ across groups with high success rates observed for men relative to women (Bortnick and Ports, 1992) and blacks relative to whites (Bortnick and Ports, 1992; Korenman and Turner, 1996; Holzer (1987). In addition, Bayer, Ross, and Topa (2004) find that both college educated workers and high school drop-outs benefit less than high school graduates from block level employment referrals. ${ }^{38}$ They also find that workers with children of similar age are more likely to successfully share employment referral information, and married women are least likely to successfully share employment referral information with each other. Ioannides and Loury (2004) provide a detailed review of this literature.

A relationship between labor market outcomes and neighborhood attributes may exist for a variety of reasons and may reflect multiple causal mechanisms. The most commonly discussed mechanisms in the literatures cited above involve information barriers to job search and the significance of informal job market referrals. Residential locations that are far from employment concentrations or have high concentrations of individuals who are not strongly attached to the labor market may provide job searchers with little opportunities for mentoring or for gathering information concerning potential job openings. On the other hand, a high quality neighborhood may provide the individual with neighborhood amenities that are complementary to leisure or may expose individuals to lower risk of adverse events that

exchange among workers, Calvo-Armengol and Jackson (2002) analyze an explicit network model of job search in which agents receive random offers and decide whether to use them themselves or pass them on to their unemployed contacts depending on their own employment status and current wage.

${ }^{37}$ See Elliot (1999) and Loury (2003) for counter examples where the use of informal networks led to lower wages. Of course, the lower wages may be associated with increased match quality on desirable job attributes causing the individual to accept a lower wage as a compensating differential.

${ }^{38}$ This finding also is consistent with assortive models of social interactions where non-college graduates use informal networks intensively, but college graduates are not part of that network. See Bertrand, Luttmer, and Mullainathan (2000), Aizer and Currie (2004), Arcidiacono and Vigdor (2004), and Weinberg (2005) for similar examples relating to welfare participation, prenatal care use, social interactions at elite universities, and social interactions among high school students, respectively. 
influence labor market productivity or behavior. For example, Kling, Liebman and Katz (2005) find that moving to a low poverty rate neighborhood improves the mental and physical health of housing voucher recipients in the Moving to Opportunity Study (MTO). In fact, the MTO study findings also suggest that there could be multiple mechanisms at work in the relationship between neighborhood and labor market outcomes. MTO implies substantial neighborhood effects on health for voucher recipients, but no influence on labor market outcomes while many studies document a positive influence of mental and physical health on labor market outcomes. ${ }^{39}$ The results from MTO and studies of health and the labor market can only be consistent if there are other influences of neighborhood poverty among MTO recipients that depress labor market activity.

Drawing on the existing literature, we first focus on three core variables: employment access drawing on the spatial mismatch literature, percent poverty which is a standard measure of neighborhood quality, and percent of college graduates which was intended to proxy for the density of human capital in the neighborhood, but appears to capture either non-linearities in neighborhood referrals or unobserved neighborhood amenities that are associated with a demand for leisure. In addition, we also extend the model to consider the effect of minority and immigrant population shares.

Sample, Control Variables, and Geography The sample of prime age adults (age 25 to 59) are drawn from confidential Long Form files of the 1990 Decennial Census for the Boston Metropolitan Statistical Area (MSA). The sample drops a small number of non-Hispanic individuals whose race is not defined as white, African-American, or Asian and Pacific Islander, as well as households residing in census tracts where employment access is not defined resulting in a sample of approximately 178,000 individuals. ${ }^{40}$

The bulk of the analysis considers three variables to describe labor market outcomes: labor force participation last week, average number of weeks worked last year conditional on working any weeks, and average hours worked per week last year conditional on having worked at least 40 weeks per year. ${ }^{41}$ Three additional labor market variables are also considered that are likely to be behaviorally related to the preceding variables: whether the individual worked any weeks last year, employment last week conditional on being a participant in the labor market, and hours worked last week if employed, see Table

\footnotetext{
${ }^{39}$ For some recent examples, See Smith (2003, 1999), Case, Lubotsky, Paxson (2002), Ettner, Frank, Kessler (1997).

40 The sample contained approximately 700 non-Hispanic individuals who did not fit into one of these racial categories. About 250 individuals resided in block groups where employment access is not defined. See Bayer, Ross, and Topa (2004) for more details on the confidential census data.

${ }^{41}$ The last two variables are truncated creating the potential for sample selection bias. As discussed above, our empirical estimates are intended to represent reduced form estimates purged of bias due to sorting and the estimates on neighborhood variables are consistent regardless of any selection or endogeneity bias in the estimates on individual attributes.
} 
1. It also should be noted that the exact sample for individual outcome variables varies because individuals are dropped from the analysis sample when an outcome is imputed.

For the purpose of describing employment outcomes as well as identifying observationally equivalent individuals, adults in the sample are described by series of categorical control variables $(Z)$ capturing the individual's education (4), age (3), race and ethnicity (4), household structure (6), gender (2), and immigration status (3) where the numbers in parentheses represent the number of categories. The labor market models also contain key interactions of gender with marital status and presence of children to address well-known aspects of female labor force participation in the United States. These variables are also used to create categories based on all permutations of the categorical variables giving rise to 1,718 cells. All prime age adults that belong to the same cell $(\Omega)$ as the individual (excepting the individual and their family members of course) are used to calculate average neighborhood attributes. The sample contains households falling into 1,632 cells, and after dropping cells with less than 10 households to reduce measurement error the final sample contains households in 996 cells. This restriction reduces the sample by less than 3,000 individuals and has no effect on any of the empirical results presented in the paper.

Each household and its members reside in a housing unit, and the location of that unit is geocoded to one of approximately 2,600 census block group in the Boston Metropolitan Area. The neighborhood is described by the following block group characteristics: percent of households in poverty, percent of individuals who are college graduates, percent individuals who are disadvantage minorities (African-American or Hispanic), and percent of individuals who were not born in the U.S.; as well as a job access measure calculated at the census tract level. The job access measure is based on an average of jobs in the same age and education category as the individual where the average is weighted based on the average commute time between the individual's residence and potential employment locations. The weights are based on the coefficient estimates arising from a gravity model, see O'Reagan and Quigley (1998). ${ }^{42}$

A proxy for unobserved neighborhood attributes is calculated as the block group mean residual from a housing price hedonic regression. These residuals are obtained by regressing the logarithm of house price and/or rent (depending upon whether owner-occupied or not) on the physical attributes of each unit: number of bedrooms, number of rooms, age of the unit, whether the unit is single family, whether a multi-family with 10 to 19 units, and whether multi-family with 20 or more units, as well as the

\footnotetext{
${ }^{42}$ The gravity model is estimated by regressing the logarithm of the number of workers commuting between two locations on the logarithms of the workers at the origination, of the jobs at the destination, and of the commute time between those locations. Typically, location combinations are dropped when no flows are observed between two locations, which can lead to a noisy measure of employment access at the census tract level. In order to mitigate this noise, we use the logarithm of one plus the flows and impute commute times using a non-parametric kernal smoother based on the cubic spline.
} 
neighborhood composition variables described above. ${ }^{43}$ As discussed earlier, the neighborhood composition arises from a household sorting process and is endogenous to location unobservables. Therefore, the housing price/rent equation is estimated using instrumental variables, and the instruments are constructed as weighted averages of the demographic composition of similar neighborhoods based on the following neighborhood housing stock variables: percent owner-occupied units, percent single family units, percent large multi-family units (greater than 20 units), percent 1 bedroom or studio units, percent 4 plus bedroom units, average age of housing stock, presence of group quarters, as well as employment access are used as instruments.

Baseline Models Table 2 presents the results for the OLS and IV estimations of the relationship between individual and neighborhood attributes and being in the labor market, weeks worked last year if working last year, and average hours worked per week if worked at least 40 weeks last year, respectively. ${ }^{44}$ The specifications presented control for individual attributes plus employment access, poverty rate, and percent of residents who graduated with a college degree from a four-year institution. The IV specification also includes a control for neighborhood unobservables based on housing prices and rents in each block group. ${ }^{45}$

Focusing on the estimates for neighborhood variables, the estimated impact of neighborhood attributes are substantially larger than the OLS estimates. Specifically, the positive impact of employment access increases dramatically for all three employment outcomes so that a one standard deviation increase in employment access implies a two percentage point increase in the likelihood of labor force participation, a one and a third of a week increase in number of weeks worked in a year, and a two and a half hour increase in hours worked per week. The negative impact of a one standard deviation increase in the poverty rate is a seven percentage point lower labor force participation rate and one week less work during the year with the impact on hours being positive and statistically insignificant. The neighborhood unobservables are also associated with more labor force participation, weeks, and hours.

The percent college educated is negatively associated with all three outcomes. This finding is

\footnotetext{
${ }^{43}$ The model is fully interactive allowing all coefficients on hedonic attributes to vary by owner-occupancy, and the logarithmic transformation allows the difference between monthly flows (rent) and value (house value) to be captured by the owner-occupancy dummy. A common dummy variable is estimated for each neighborhood using all housing units in that neighborhood whether rental or owner-occupied. The use of a common variable to capture neighborhood quality regardless of owner-occupancy status seems reasonable given the small geographic area considered implying that all housing units that share a fixed effect are located in close proximity with each other.

${ }^{44}$ The estimates for individual attributes also appear reasonable. Focusing on labor force participation, males have higher participation rates, participation falls between 45 and 59, participation rises with education, increases for married males especially with kids, and decreases for married females especially with young children.

${ }^{45}$ As mentioned earlier, the expected neighborhood exposure based cell averages is quite predictive of an individual's actual neighborhood exposure suggesting that our instruments have sufficient power. As discussed earlier, several robust checks, comparable to overidentification tests, are conducted in order to assess whether our estimates are robust to eliminating various sources of identifying information.
} 
consistent with previous findings that labor market referrals are used less intensively by individuals with higher levels of education (Ioannides and Loury, 2004) and that college educated individuals may both benefit less from and contribute less to informal job networks (Bayer, Ross, and Topa, 2004). Alternatively, percent college educated may capture local amenities that are complementary to leisure and non-market home production activities. For example, individuals residing in locations with neighbors who have a higher level of education may simply enjoy working less and spending more time at home. As discussed, this explanation might help explain why Moving to Opportunity finds a positive impact of neighborhood on health, but no impact of neighborhood on labor market outcomes. Presumably, the lower poverty rates lead to superior health outcomes and an associated increase in labor market potential, but the exposure to more college educated individuals decreases labor market outcomes.

The finding that OLS estimates of neighborhood effects are biased downwards is consistent with the hypothesis that individuals with poor unobservables in terms of labor market outcomes compensate for these unobservables by sorting into locations with better employment prospects. Specifically, the bias in OLS is consistent with neighborhood quality being negatively correlated with individual unobserved attributes that contribute to labor market success. In the neighborhood effects literature, researchers have often expected to find positive selection where high quality workers reside in high quality locations. While this view makes considerable sense when considering the demand for neighborhood amenities related to quality of life, it is less clear that positive selection will arise on variables that impact labor market participation, such as employment access or the quality of informal job networks. High skill workers with strong attachment to the labor market may be less willing than workers with weak labor market attachment to give up neighborhood quality of life amenities in exchange for access to urban environments with good labor market information and low job search costs.

Table 3 presents the results for alternative education subsamples with the first panel presenting the full sample results and the next two panels containing subsamples after dropping individuals with four-year college degrees or dropping individuals with two or more years of college, respectively. The effect of employment access and poverty on labor force participation increases in magnitude as high human capital individuals are eliminated from the sample. This pattern should be expected if the influence of employment access and poverty on labor force participation is driven primarily by neighborhood contributions to job networks. Similarly, the effect of poverty on weeks worked increases in magnitude, and the effect of poverty on hours becomes negative but is still insignificant. ${ }^{46}$ On the other hand, the negative effect of employment access on weeks per year and hours per week worked is quite stable as college educated workers are dropped from the sample. This result is not very surprising. The

\footnotetext{
${ }^{46}$ This suggests a larger positive effect of poverty on hours for the college educated. This finding may represent a neighborhood amenities story with high education individuals disliking spending time at home when they reside in high poverty rate neighborhoods and responding to this dislike by working more hours.
} 
models are estimated for people who are already in the labor market so that the influence of job access is likely to represent costs associated with commuting to an existing job. Commuting costs are often primarily time costs, which actually rise with human capital levels. ${ }^{47}$ Table 4 presents a similar exercise dropping white collar workers and shows that the importance of employment access for labor force participation is larger for non-white collar workers.

The negative effect of percent college educated on labor force participation falls for lower skill populations. This effect might be expected to increase in magnitude if this relationship was driven by the availability of job market referrals since non-college graduates would appear to be least likely to benefit from referrals provided by college graduates. The decline in the variable's effect for populations with lower human capital may reflect a lower demand for these neighborhood amenities among low human capital individuals and therefore less substitution towards leisure among non-college educated. Again, Table 4 mirrors the results for education with non-white collar workers experiencing a smaller negative relationship between the presence of college graduates in a neighborhood and labor force participation.

Table 5 presents estimates for subsamples based on gender and family structure. The table focuses on a series of subsamples that are designed to represent increased attachment to the labor market by first dropping married females with children from the sample, then dropping all married females, and finally dropping all females from the sample and focusing only on prime-age males. The results are quite striking. All estimates for the four neighborhood variables decline in magnitude and many become statistically insignificant suggesting that women and especially married women are driving our findings. As in Tables 3 and 4, this table further supports the idea that neighborhoods matter most for the labor market activity of individuals who are not strongly attached to the labor market.

Decomposing the Effects of the Identification Strategy Table 6 presents the estimates on the neighborhood variables for a series of specifications. The first column presents the results from OLS, and the second column presents the results from a second stage estimation where the neighborhood fixed effects from labor market models are regressed upon neighborhood variables. The third column contains estimates for a simple instrumental variable model where the three neighborhood variables are predicted using the expected exposure level based on observationally equivalent individuals. The final three columns add a housing price residual from a simple housing price hedonic using ordinary least squares, instrument for that residual based on observationally equivalent individuals, and finally instrument for an unbiased residual arising from using IV in the housing price/rent model.

The main conclusion arising from this table is that the increase in the importance of neighborhood variables arises from instrumenting for those variables in order to break the link between those

\footnotetext{
${ }^{47}$ See Ross and Zenou (2004) for a study that examines the relationship between commute time and labor market outcomes.
} 
neighborhood variables and the individual unobservable. The two stage fixed effect estimates look nothing like the results from the IV specification, and the IV specifications are broadly similar in terms of the effect of observed neighborhood attributes. In addition, the housing price residual does not matter until an instrument is used to break the correlation between those neighborhood unobservables and individual unobservables. The overall effect of neighborhood appears to be smaller in the final IV specification as compared the intermediate IV specifications suggesting that the effect of neighborhood may in some cases be overstated when the model does not correctly control for sorting over location specific unobservables.

As discussed earlier, these findings are consistent with a compensation strategy where individuals with lower likelihoods of employment seek out neighborhoods that provide the best opportunity for employment. Of course, the negative correlation between individual labor market unobservables and neighborhood contribution to labor market outcomes may be driven by tastes over neighborhood attributes. For example, individuals with poor labor market unobservables may also exhibit the weakest preference for positive amenities associated with neighborhoods that have poor job access or attract a large number of college graduates based on their housing stock, and as a result these individuals reside in neighborhoods that provide better job market opportunities. On the other hand, the influence of location unobservables appears to arise from positive selection where individuals with high taste observables reside in neighborhoods with positive neighborhood unobservables in terms of labor market outcomes.

Exploring Neighborhood Determinants Table 7 presents a series of specifications starting with no neighborhood controls except for the housing market residual and then expanding the list of controls to add poverty, employment access, percent with a four-year college education, percent disadvantaged minorities, and finally percent not born in the United States in sequence. A unique set of neighborhood housing price residuals is constructed for each specification where the residual is conditional on the same set of neighborhood controls that were included in the labor market equation. For example, in the no neighborhood control specification, the housing price regression contains no neighborhood controls, and the housing price residual captures the net impact of all aspects of neighborhood quality that are reflected in housing prices.

The key finding of a large negative impact of poverty on labor force participation and weeks worked is quite robust across specifications. The estimated coefficients are similar in magnitude whether or not the specification includes employment access and percent college educated and the magnitude increases with the inclusion of the share minority and immigrant because those neighborhood variables, especially share immigrant, appear to be associated with higher levels of work on all three measures. Neighborhoods with a high share of immigrants may provide especially fertile ground for job referrals and other aspects of the informal job search process. The positive impact of employment access on weeks 
worked and hours appears robust, but the magnitude declines as the share minority and immigrant variables are included. Employment access appears to have no impact on labor force participation after including the minority and immigration composition variables. ${ }^{48}$ The negative relationship between percent college educated and labor market outcomes is very stable for all three outcome variables.

The estimated coefficient on neighborhood quality is much smaller in magnitude for all three labor market outcomes and negative for weeks and hours worked in the model that does not contain any other neighborhood variables. In this model, the neighborhood quality variable captures the net effect of neighborhood given the correlation between different factors that arise in equilibrium, and this net affect appears to be smaller than the individual effects of neighborhood attributes and ambiguous in sign. In equilibrium, the share of college graduates is negatively correlated with poverty rates, and yet both variables reduce the rate and intensity of labor force participation. In practice, they likely cancel out leading to little net influence of neighborhood quality (as captured by price) on labor market outcomes. Once the college degree variable is included, the sign on the housing price residual is consistently positive and the estimated magnitudes are quite stable. Whether the variable captures the low referral contribution of college graduates or consumption amenities that increase the demand for leisure, the inclusion of this variable separates two sets of neighborhood unobservables that are both positively correlated with price based measures of neighborhood quality, but have conflicting impacts on labor market outcomes.

Additional Validation and Robustness Efforts Table 8 presents estimates of the relationship between capital income and neighborhood variables in order to see whether our identification strategy implies unrealistically large impacts of neighborhood attributes on capital income. Such findings would suggest that our identification strategy is flawed. Capital income is very noisy and attempts to estimate linear models of capital income did not provide credible estimates on individual attributes. For example, these analyses found no statistically significant relationship between age or education and capital income. In order to mitigate the effect of noise in the self-reported capital income, we focus on three binary variables, which were defined as zero if the individual had between zero capital income and some positive threshold, one if they had capital income above that threshold, and missing if capital income is not reported, imputed or negative. The three thresholds used are $\$ 0, \$ 1,000$, and $\$ 3,000$.

Employment access, percent college educated, and in some cases poverty are all correlated with capital income as indicated by the simple OLS regressions. The estimates on neighborhood variables from the instrumental variable specifications are always statistically insignificant and almost always smaller that the estimates arising from OLS. The one exception is the coefficient on poverty in the model

\footnotetext{
${ }^{48}$ The fact that the employment access estimates may not be robust to the inclusion of additional neighborhood variables should not be surprising. Remember, unlike the neighborhood demographic composition variables, job access is assumed exogenous to neighborhood unobservables, which will lead bias due to omitted minority and immigration variables if job access is correlated with omitted neighborhood variables that attract those populations.
} 
for whether capital income is above $\$ 3,000$. Even for this estimate, the magnitude of the effect is quite small with a one standard deviation in poverty leading to a less than one percent change in likelihood of having capital income above $\$ 3,000{ }^{49}$

Table 9 presents the results for three alternative indicators of labor market outcomes: whether worked any weeks last year, whether employed last week, and number of hours worked last week if employed. These variables parallel the three dependent variables used for most of the analysis with worked last year capturing behaviors related to labor force participation, employed last week capturing the risk of unemployment that might reduce the number of week worked in any year, and hours last week capturing behaviors similar to those captured by average hours worked per week last year. The first panel contains the results for the original three outcome variables and the second contains the results for these three alternative variables. The estimated effects of neighborhood attributes based on the original variables and based on the alternative dependent variables are quite similar. ${ }^{50}$

Table 10 incorporates a control for the quality of the housing stock in a neighborhood, which is an aggregation of the same housing stock variables used to instrument for neighborhood composition variables. The original IV specification and the specification that includes this control for housing stock are shown side by side. A quick comparison confirms that the magnitudes of all estimated coefficients are quite stable to the inclusion of a housing stock control into both the labor market and housing price/rent models. The reader should note that the model includes the actual housing stock rather than an instrument based on the exposure of observationally equivalent households. The inclusion of the housing stock control is intended to assure that the housing price residual is identified by unexplained variation in housing prices rather than a housing stock exclusion restriction, and the large and significant coefficient estimate on housing stock represents sorting bias rather than any direct effect of neighborhood housing stock on labor market outcomes. ${ }^{51}$

\section{Summary and Conclusions}

In this paper, we consider the general problem of identifying the effect of individual and group attributes on individual outcomes in a model that allows for both individual and group unobservables. We begin by using a simple vertical model of sorting to highlight the complex set of correlations that arise even in a simple model of residential location choice. We then offer a non-parametric solution to

\footnotetext{
${ }^{49}$ A reader might question whether the increasingly positive coefficient on poverty in the IV specification might represent a trend and become large and significant for higher thresholds. We examined models with higher capital income thresholds and did not find any such trend.

50 The participation and hours variables are directly comparable to each other in magnitude. The estimates in the employment and weeks worked equations are not, but one can verify that the relative magnitudes of the coefficient estimates from the two models are quite close.

${ }^{51}$ Results are also robust to a model that instruments for housing stock, and in that model housing stock is not statistically significant.
} 
this identification problem that is grounded in the structure of vertical sorting equilibria. In particular, we exploit the monotonic relationship between neighborhood housing prices and neighborhood quality in equilibrium to show that a flexible function of neighborhood housing prices serves as a suitable control function for the neighborhood unobservable in the labor market outcome regression. By including this control function, we eliminate the group unobservable from the regression, thereby reducing the problem to a more standard selection problem with a single individual-level unobservable.

To address this more standard selection problem, we use aggregation to develop suitable instruments for both exogenous and endogenous group attributes. Instrumenting for each individual's observed neighborhood attributes with the average neighborhood attributes of a set of observationally identical individuals eliminates the portion of the variation in neighborhood attributes due to sorting on unobserved individual attributes.

To illustrate our proposed methodology, we estimate a wide variety of labor market models using confidential data on the Boston Metropolitan Area from the 1990 census long form. We find that neighborhood has large and complex affects on labor market outcomes. Employment access, low levels of poverty, a low fraction of college graduates, and high levels of unobserved neighborhood attributes are all associated with higher levels of labor force participation, greater number of weeks worked in a year, and with the exception of poverty greater average number of hours worked per week. The estimated effects of neighborhood variables are economically meaningful with for example a one standard deviation increase in employment access leading to approximately a four percentage point increase in labor force participation in the subsample of individuals who have never attended college. Moreover, the estimated effects are substantially larger than estimates arising from ordinary least squares suggesting that individuals with a lower likelihood of obtaining employment have sorted into locations with superior labor market opportunities potentially to compensate for their poor unobservables. It is notable that the core results in the paper are robust across many outcomes variables and a wide variety of specifications.

As expected, the positive impact of low neighborhood poverty rates and good job access on labor force participation increases as high human capital individuals or white collar workers are deleted from the sample. The existing literature suggests that these individuals are least likely to benefit from informal labor market referral networks. On the other hand, the positive impact of good job access on the intensity of labor force participation as captured by weeks per year and hours per week does not change as the human capital level of the sample falls. This finding may in part be due to the fact that high human capital individuals have a high cost of time and therefore may substitute away from work as commutes increase. The effects over gender are even more striking all findings decline in magnitude and many become statistically insignificant as married women and eventually all women are deleted from the sample. Overall, the results indicate that neighborhood effects are most important for individuals with weak attachment to the labor market, especially married women. 
While the effect of individual variables appears large, the net effect of neighborhood quality is actually quite small as illustrated by the model that just includes one variable for neighborhood quality. This finding appears to be driven by the strong negative effect of the percent of college graduates in a neighborhood on labor market outcomes. Neighborhoods with low poverty rates and other attributes that positively impact labor market outcomes appear correlated with the percent of college graduates in equilibrium. These competing effects lead to small and sometimes negative relationships between overall neighborhood quality and various labor market outcomes, which is consistent with findings in the Moving to Opportunity program that improvements in neighborhoods quality had little or no impact on earnings. Moreover, these findings help explain a puzzle in the MTO results. Voucher recipients in MTO experience improved health outcomes, but do not experience the improvement in labor market outcomes often associated with improvements in physical and mental health. The positive effects of improved health on labor market potential may have been counteracted by other influences of neighborhood that lead to reduced labor supply.

These findings suggest that a richer understanding of the relationship between neighborhood and economic self-sufficiency is required to address the high unemployment rates and low incomes occurring in poor, central city neighborhoods. High poverty rate neighborhoods appear to have a large negative affect on labor market outcomes, especially for low human capital populations. This large effect might be attributable in part to the negative impacts of high poverty locations on health and emotional well being found in the Moving to Opportunity program. Future mobility programs should take into account the possibility that small net effects of neighborhood quality hide large positive and negative impacts on labor market outcomes. For example, the potential negative impact of moving on informal referral networks may in part be offset by increased provision of formal job search support.

\section{References}

Addison, John T. and Pedro Portugal. 2002. Job Search Methods and Outcomes. Oxford Economics Papers, 54 (3), 505-33.

Aizer, Anna and Janet Currie. 2004. Networks or Neighborhoods? Correlations in the Use of PubliclyFunded Maternity Care in California. Journal of Public Economics, 88 (12), 2573-85.

Ananat, Elizabeth. 2007. The Wrong Side(s) of the Tracks: Estimating the Causal Effects of Segregation on City Outcomes. NBER Working Paper \#13343.

Angrist, Joshua, Guido Imbens, and Donald Rubin. 1996. Identification of Causal Effects Using Instrumental Variables Journal of the American Statistical Association, 91(434), 444-455.

Arcidiacono, Peter and Jacob Vigdor. 2004. On the Value of Inter-Racial Contact and Affirmative Action as a Means to Achieve It. Duke University unpublished manuscript.

Bajari, Patrick, and Lanier Benkard. 2005. Demand Estimation with Heterogeneous Consumers and Unobserved Product Characteristics: A Hedonic Approach Journal of Political Economy, 113(6), 1239-76. 
Bajari, Patrick, and Matthew Kahn. 2005. Estimating Housing Demand with and Application to Explaining Racial Segregation in Cities. Journal of Business and Economic Statistics, 23(1), 2033.

Bayer, Patrick, Robert McMillan, Kim Rueben. 2005. An Equilibrium Model of Sorting in an Urban Housing Markets. NBER Working Paper No. 10865

Bayer, Patrick, Stephen L. Ross, Giorgio Topa. In Press. Place of Work and Place of Residence: Informal Hiring Networks and Labor Market Outcomes. Journal of Political Economy,

Bayer, Patrick and Christopher Timmons. 2005. On the Equilibrium Properties of Locational Sorting Models. Journal of Urban Economics, 57(3), 462-77.

Bayer, Patrick and Christopher Timmons. 2006. Estimating Equilibrium Models of Sorting across Locations. Economic Journal, forthcoming.

Benabou, Roland. 1993. The Workings of a City: Location, Education, and Production. Quarterly Journal of Economics, 108(3), 619-52.

Benabou, Roland. 1996. Heterogeneity, Stratification, and Growth: Macroeconomic Implications of Community Structure and School Finance, American Economic Review, 86(3), 584-609.

Bertrand, Marianne, Erzo Luttmer, and Sendhil Mullainathan. 2000. Network Effects and Welfare Cultures. Quarterly Journal of Economics, 115 (3), 1019-55.

Blau, David and Phillip Robbins. 1990. Job Search Outcomes for the Employed and Unemployed. Journal of Political Economy, 98 (3), 637-55

Blau, David. 1992. An Empirical Analysis of Employed and Unemployed Job Search Behavior, Industrial and Labor Relations Review, 45, 738-52.

Bortnick, Steven and Michelle Ports. 1992. Job Search Methods and Results: Tracking the Unemployed, Monthly Labor Review, 115(12), 29-35.

Brock, William A. and Stephen N. Durlauf. 2006. Identification of Binary Choice Models with Social Interactions. Journal of Econometrics, forthcoming.

Brock, William A. and Stephen N. Durlauf. 2005. A Multinomial Choice Model with Social Interactions. In L. Blume, S. Durlauf eds., The Economy as and Evolving Complex System III, Oxford: Oxford University Press: New York, 175-206

Brock, William A. and Stephen N. Durlauf. 2002. A Multinomial Choice Model of Neighborhood Effects. American Economic Review, 92, 298-303.

Brock, William A. and Steven N. Durlauf. 2001. Discrete choice with social interactions. Review of Economic Studies, 68, 235-260.

Calvo-Armengol, Antoni and Matthew O. Jackson. 2004. The Effects of Social Networks on Employment and Inequality, American Economic Review, 94 (3), 426-54.

Calvo-Armengol, Antoni, Eleonora Patacchini and Yves Zenou. In Press. Peer Effects and Socail Networks in Education, Review of Economic Studies.

Card, David and Jesse Rothstein. 2007. Racial Segregation and the Black-White Test Score Gap, Journal of Public Economics,

Case, Anne C. and Lawrence F. Katz. 1991. The Company You Keep: The Effects of Family and Neighborhood on Disadvantaged Youths. NBER Working Paper No. 3705.

Case, Anne C., Darren Lubotsky, Chris Paxson. 2002. Economic Status and Health in Childhood: The Origin of the Gradient. American Economic Review, 92, 1308-1334.

Corcoran, Mary, Linda Datcher and Greg Duncan. 1980. Information and Influence Networks in Labor Markets, in Five Thousand American Families: Patterns of Economic Progress, edited by Greg Duncan and James Morgan, 7, 1-37, Ann Arbor, MI: Institute For Social Research.

Cutler, David and Edward Glaeser. 1997. Are Ghettos Good or Bad? Quarterly Journal of Economics, $112,827-872$.

Dahl, Gordon. 2002. Mobility and the Return to Education: Testing a Roy Model with Multiple Markets. Econometrica, 70, 2367-420.

Durlauf, Steven. 2004. Neighborhood Effects. In The Handbook of Regional and Urban Economics, Volume 4: Cities and Geography, edited by V. Henderson and J.F. Thisse. Elsevier Science/North Holland 
Devine, Theresa and Nicholas Kiefer. 1991. Empirical Labor Economics: The Search Approach, New York: Oxford University Press.

Ekeland, Ivar, James Heckman, and Lars Nesheim. 2004. Identification and Estimation of Hedonic Models. Journal of Political Economy, 112(1.2), S60-S108.

Elliot, James. 1999. Social Isolation and Labor Market Isolation: Network and Neighborhood Effects on Less-Educated Workers. Sociological Quarterly, 40 (2), 199-16.

Epple, Dennis. 1987. Hedonic Prices and Implicit Markets: Estimating Demand and Supply Functions for Differentiated Products. Journal of Political Economy, 95(1): 59-80.

Epple, D., R. Filimon, and T. Romer. 1984. Equilibrium Among Local Jurisdictions: Towards an Integrated Approach of Voting and Residential Choice. Journal of Public Economics, 24, 281304.

Epple, D., R. Filimon, and T. Romer. 1993. Existence of Voting and Housing Equilibrium in a System of Communities with Property Taxes. Regional Science and Urban Economics, 23, 585-610.

Epple, Dennis and Glen J. Platt. 1998. Equilibrium and Local Redistribution in an Urban Economy when Households Differ in Both Preferences and Incomes. Journal of Urban Economics, 43, 23-51.

Epple, Dennis and Richard Romano. 1998. Competition between Private and Public Schools, Vouchers, and Peer-Group Effects. American Economic Review, 88(1), 33-62.

Epple, Dennis and Thomas Romer. 1991. Mobility and Redistribution, Journal of Political Economy, 99(4), 828-58.

Epple, Dennis, Thomas Romer and Holger Sieg. 2001. Interjurisdictional Sorting and Majority Rule: An Empirical Analysis. Econometrica, 69(6), 1437-55.

Epple, Dennis and Holger Sieg. 1999. Estimating Equilibrium Models of Local Jurisdictions. Journal of Political Economy, 107, 645-681.

Ellen, Ingrid and Margery A. Turner. 1997. Does Neighborhood Matter? Assessing Recent Evidence. Housing Policy Debate, 8, 833-866.

Ettner, Susan L., Richard G. Frank, and Ronald C. Kessler. 1997. The Impact of Psychiatric Disorders on Labor Market Outcomes. Industrial and Labor Relations Review, 51, 64-81.

Evans, Willian, Wallace Oates, and Robert Schwab. 1992. Measuring Peer Group Effects: A Study of Teenage Behavior. Journal of Political Economy, 10, 966-991.

Fernandez, Raquel and Richard Rogerson. 1996. Income Distribution, Communities, and the Quality of Public Education. Quarterly Journal of Economics, 111(1), 135-164.

Fernandez, Raquel and Richard Rogerson. 1998. Public Education and Income Distribution: A Dynamic Quantitative Evaluation of Education Finance Reform. American Economic Review, 88(4), 81333.

Ferreira, Fernando. 2003. You Can Take It with You: Transferability of Proposition 13 Tax benefits, Residential Mobility, and Willingness to Pay for Housing Amenities. University of Pennsylvania unpublished manuscript.

Ferreyra, Maria. 2003. Estimating the Effects of Private School Vouchers in Multi-District Economies. Carnegie-Mellon University unpublished manuscript.

French, Eric. 2005. The Effects of Health, Wealth, and Wages on Labor Supply and Retirement Behavior. Review of Economic Studies, 72, 395-427.

French, Eric and John Bailey Jones. 2008. The Effects of Health Insurance and Self-Insurance on Retirement Behavior. SUNY Albany Working Paper.

Fu, Shihe and Stephen L Ross. 2007. Wage Premia in Employment Clusters: Agglomeration or Worker Heterogeneity. University of Connecticut Working Paper.

Geweke, John, Gautam Gowrisankaran, and Robert Town 2003. Bayesian Inference for Hospital Quality in a Selection Model. Econometrica Vol 71, pp. 1215-48.

Granovetter, Mark S. 1995. Getting a Job: A Study of Contacts and Careers. Cambridge, MA: Harvard University Press.

Grinblatt, Mark, Matti Keloharju, and Seppo Ikaheimo. 2004. Interpersonal Effects in Consumption: Evidence from the Automobile Purchases on Neighbors. NBER Working Paper \#10226. 
Heckman, James. 1979. Sample Selection Bias as a Specification Error. Econometrica, 47(1), 153-162

Heckman, James. 1990. Varieties of Selection Bias. American Economic Review. 80: 313-18.

Heckman, James and Edward Vytlacil. 2001. Local Instrumental Variables,. in Nonlinear Statistical Inference: Essays in Honor of Takeshi Amemiya, C. Hsiao, K. Morimune, and J. Powell (editors), (Cambridge: Cambridge University Press).

Holzer, Harry. 1987. Informal Job Search and Black Youth Unemployment. American Economic Review, 77(3), 446-52.

Holzer, Harry. 1988. Search Method Use by Unemployed Youth. Journal of Labor Economics, 6(1), 120.

Ihlanfeldt, Keith. 2000. The Spatial Mismatch Hypothesis: A Review of Recent Studies and Their Implications for Welfare Reform. Housing Policy Debate, 9, 849-892.

Ihlanfeldt, Keith. 1992. Job Accessibility and the Employment and School Enrollment of Teenagers. Kalamazoo, MI: W.E. Upjohn Institute for Employment Research.

Ihlanfeldt, Keith and David Sjoquist. 1990. Job Accessibility and Racial Differences in Youth Employment Rates. American Economic Review, 80, 267-276.

Ioannides, Yannis M. and Linda Datcher Loury. 2004. Job Information Networks, Neighborhood Effects, and Inequality. Journal of Economic Literature, 42, 1056-93.

Ioannides, Yannis M. and Giulio Zanella. 2008. Neighborhood Effects and Neighborhood Choice: Testing Necessary Condtions. Working Paper.

Ioannides, Yannis M. and Jeffrey Zabel. 2008. Interactions, Neighborhood Selection and Housing Demand. Journal of Urban Economics, 63, 229-52.

Jacob, Brian. 2004. Public Housing, Housing Vouchers and Student Achievement: Evidence from Public Housing Demolitions in Chicago, American Economic Review, 94(1), 233-58.

Kain, John. 1968. Housing Segregation, Negro Employment, and Metropolitan Decentralization. Quarterly Journal of Economics, 82, 175-197.

Katz, Lawrence F., Jeffrey Kling and Jeffrey Liebman. 2001. Moving To Opportunity in Boston: Early Results of a Randomized Mobility Experiment. Quarterly Journal of Economics, 116, 607-54.

Kling, Jeffrey, Jeffrey Liebman and Lawrence F. Katz. 2005. Experimental Analysis of Neighborhood Effects. NBER Working Paper No. 11577.

Kling, Jeffrey, and Jens Ludwig. 2007. Is Crime Contagious? Journal of Law and Economics, 50, 491518.

Kling, Jeffrey, Jens Ludwig, and Lawrence F. Katz. 2005. Neighborhood Effects on Crime for Female and Male Youth: Evidence from a Randomized Housing Voucher Experiment. Quarterly Journal of Economics, 120, 87-130.

Korenman, Sanders and Susan Turner. 1996. Employment Contacts and Minority-White Wage Differences. Industrial Relations, 35 (1), 106-22.

Loury, Linda Datcher. 2003. Some Job Contacts are More Equal Than Others: Earnings and Job Information Networks. Tufts University, unpublished manuscript.

Ludwig, Jens, Greg Duncan, and Joshua Pinkston. 2005. Housing Mobility Programs and Economic SelfSufficiency: Evidence from a Randomized Experiment. Journal of Public Economics, 89, 13156.

Manski, Charles F. 1993. Identification of Endogenous Social Effects: the Reflection Problem. Review of Economic Studies, 60, 531-542.

Marmaros, David and Bruce Sacerdote 2002. Peer and Social Networks in Job Search, European Economic Review, 46, 870-879.

Mayer, Christopher. 1996. Does Location Matter? New England Economic Review, May/June, 26-40.

Moffitt, Robert. 2001. Policy Interventions, Low-Level Equilibria and Social Interactions. In Social Dynamics, edited by Steven N. Durlauf and H. Peyton Young. Cambridge, Mass.: MIT Press.

Montgomery, James D. 1991. Social Networks and Labor-Market Outcomes: Toward an Economic Analysis. The American Economic Review, 81(5), 1408-18. 
Nechyba, Thomas. 1999. School Finance Induced Migration and Stratification Patterns: the Impact of Private School Vouchers. Journal of Public Economic Theory, 1.

Nechyba, Thomas. 2000. Mobility, Targeting, and Private School Vouchers. American Economic Review, 90(1): 130-46.

O'Regan, Kathy and John Quigley. 1998. Teenage Employment and the Spatial Isolation of Minority and Poverty Households. Urban Studies, 35, 1187-1205

Oreopoulos, Philip. 2003. The Long-Run Consequences of Living in a Poor Neighborhood. Quarterly Journal of Economics, 118(4), 1533-75.

Patacchini, Eleonora and Yves Zenou. 2003. Juvenile Delinquency and Conformism, working paper

Petrin, Amil and Kenneth Train. 2002. Omitted Product Attributes in Discrete Choice Models. University of California-Berkeley unpublished manuscript.

Popkin, Susan J., James E. Rosenbaum and Patricia M. Meaden. 1993. Labor Market Experiences of Low-Income Black Women in Middle-Class Suburbs: Evidence from a Survey of Gautreaux Program Participants. Journal of Policy Analysis and Management, 12, 556-73.

Raphael, Steven. 1998. The spatial mismatch hypothesis and black youth joblessness. Journal of Urban Economics 43, pp. 79-111.

Rees, Albert and George P. Schultz. 1970. Workers and Wages in an Urban Labor Market, Chicago: Univ. of Chicago Press.

Ross, Stephen L. 1998. Racial Differences in Residential and Job Mobility. Journal of Urban Economics, 43, 112-36.

Ross, Stephen L. and John Yinger. 1999. Urban Public Finance. In The Handbook of Regional and Urban Economics, Volume 3: Applied Urban Economics, edited by Paul Cheshire and Edwin S. Mills. Elsevier Science/North Holland.

Ross, Stephen L. and Yves Zenou. In Press. Shirking, Commuting and Labor Market Outcomes.Regional Science and Urban Economics.

Rothstein, Jessie. 2008. Student Sorting and Bias in Value Added Estimations: Selection on Observables and Unobservables. Princeton University Working Paper.

Sacerdote, Bruce. 2001, Peer Effects with Random Assignment: Results for Dartmouth Roommates. Quarterly Journal of Economics, 116 (2), 681-704.

Sieg, Holger, V. Kerry Smith, H. Spencer Banzaf and Randall Walsh. 2002. Interjurisdictional Housing Prices in Locational Equilibrium. Journal of Urban Economics. 52 (1), 131-153.

Sieg, Holger, V. Kerry Smith, H. Spencer Banzaf and Randall Walsh. 2004. Estimating the General Equilibrium Benefits of Large Changes in Spatially Delineated Public Goods. International Economic Review. 45(4), 1047-77.

Smith, James P. 1999. Healthy Bodies and Thick Wallets. Journal of EconomicsPerspectives, 13(2), 145166.

Smith, James P. 2003. Consequences and Predictors of New Health Events. NBER Working Paper No. 10063.

Wahba, Jackline and Yves Zenou. 2003. Density, Social Networks and Job Search Methods: Theory and Application to Egypt, CEPR Working Paper \#3967.

Walsh, Randall. 2004. Endogenous Open Space Amenities in a Locational Equilibrium. CEA Working Paper No. 04-03, February.

Weinberg, Bruce. 2004. Testing the Spatial Mismatch Hypothesis Using Inter-city Variations in Industrial Composition. Regional Science and Urban Economics, 34(5): 505-32.

Weinberg, Bruce. 2005. Social Interactions and Endogenous Association. Ohio State University, unpublished manuscript.

Weinberg, Bruce. 2000. Black Residential Centralization and the Spatial Mismatch Hypothesis. Journal of Urban Economics, 48, 110-34.

Weinberg, Bruce, Patricia Reagan and Jeffrey Yankow. Forthcoming. Do Neighborhoods Affect Hours Worked: Evidence from Longitudinal Data. Journal of Labor Economics.

Zax, Jeffrey and John Kain. 1991. Commutes, Quits, and Moves. Journal of Urban Economics, 29, 15365. 
Zenou, Yves. 2000. Unemployment in Cities. In Economics of Cities: Theoretical Perspectives, edited by J. Huriot and J. Thisse. Cambridge: Cambridge University Press. 


\begin{tabular}{|l|l|c|}
\hline \multicolumn{3}{|l|}{ Table 1: Variable Names, Description, Means, and Standard Deviations } \\
\hline Variables & Variable Description & Means \\
\hline Respondent Outcome Variables & 0.854 \\
\hline Labor Force & $\begin{array}{l}\text { One if respondent was working or looking for work at the time } \\
\text { Participant }\end{array}$ & $(0.352)$ \\
\hline Weeks Worked & Total number of weeks worked last year; missing if no weeks & 40.105 \\
Last Year & worked last year & $19.228)$ \\
\hline Weekly Hours & Average number of hours worked per week last year; missing & 34.388 \\
Last Year & if worked less than 40 weeks last year & $(17.635)$ \\
\hline Worked Last & One if respondent worked any weeks last year & 0.856 \\
Year & & $(0.350)$ \\
\hline Employed Last & One if respondent was employed last week, zero if & 0.811 \\
Week & unemployed and a labor force participant, missing otherwise & $(0.390)$ \\
\hline Hours Worked & Number of hours worked last week; missing if not employed & 32.551 \\
Last Week & last week & $19.750)$ \\
\hline Positive Capital & One if respondent has positive capital income; missing if & 0.453 \\
Income & capital income negative, imputed or not reported & $(0.498)$ \\
\hline Capital Income & One if respondent has positive capital income; missing if & 0.307 \\
$>1000$ & capital income negative, imputed or not reported & $(0.461)$ \\
\hline Capital Income & One if respondent has positive capital income; missing if & 0.268 \\
$>3000$ & capital income negative, imputed or not reported & $(0.443)$ \\
\hline
\end{tabular}

Notes: Standard deviations are shown in parentheses. 


\begin{tabular}{|c|c|c|}
\hline Variables & Variable Description & Means \\
\hline \multicolumn{3}{|c|}{ Categorical Respondent Control Variables } \\
\hline Male & One if respondent male (omitted category female) & $\begin{array}{c}0.482 \\
(0.499)\end{array}$ \\
\hline Age $35-44$ & $\begin{array}{l}\text { One if respondent between } 35 \text { and } 44 \text { years of age (omitted } \\
\text { category } 25 \text { to } 34 \text { years) }\end{array}$ & $\begin{array}{r}0.317 \\
(0.465)\end{array}$ \\
\hline Age 45-59 & One if respondent between 45 and 59 years of age & $\begin{array}{c}0.302 \\
(0.459)\end{array}$ \\
\hline Black & $\begin{array}{l}\text { One if respondent non-Hispanic Black (omitted category non- } \\
\text { Hispanic white) }\end{array}$ & $\begin{array}{r}0.047 \\
(0.210) \\
\end{array}$ \\
\hline Hispanic & One if respondent Hispanic & $\begin{array}{c}0.033 \\
(0.178) \\
\end{array}$ \\
\hline Asian & One if respondent Asian or Pacific Islander & $\begin{array}{r}0.029 \\
(0.167) \\
\end{array}$ \\
\hline No High School & $\begin{array}{l}\text { One if respondent did not graduate from high school (omitted } \\
\text { category high school graduate) }\end{array}$ & $\begin{array}{c}0.099 \\
(0.298)\end{array}$ \\
\hline Some college & $\begin{array}{l}\text { One if respondent finished at least two years of college but } \\
\text { does not have four year degree }\end{array}$ & $\begin{array}{c}0.247 \\
(0.431)\end{array}$ \\
\hline College & One if respondent gradudated with a four year college degree & $\begin{array}{c}0.404 \\
(0.490) \\
\end{array}$ \\
\hline $\begin{array}{l}\text { Single } \\
\text { Independent }\end{array}$ & $\begin{array}{l}\text { One if respondent single and not living with family (omitted } \\
\text { category married not residing with own children under age 18) }\end{array}$ & $\begin{array}{c}0.224 \\
(0.417)\end{array}$ \\
\hline Single parent & $\begin{array}{l}\text { One if respondent is a single parent residing with their minor } \\
\text { child }\end{array}$ & $\begin{array}{r}0.094 \\
(0.291)\end{array}$ \\
\hline Single w/ family & $\begin{array}{l}\text { One if respondent is single and living with family members } \\
\text { other than their children }\end{array}$ & $\begin{array}{c}0.051 \\
(0.219)\end{array}$ \\
\hline $\begin{array}{l}\text { Married w/ } \\
6<=\text { kids }<18\end{array}$ & $\begin{array}{l}\text { One if respondent is married and residing with their minor } \\
\text { children, but no children less than } 6\end{array}$ & $\begin{array}{c}0.179 \\
(0.383)\end{array}$ \\
\hline $\begin{array}{l}\text { Married w/ } \\
\text { kids }<6\end{array}$ & $\begin{array}{l}\text { One if respondent married residing with own child under } 6 \\
\text { (omitted category married with no children) }\end{array}$ & $\begin{array}{r}0.187 \\
(0.390) \\
\end{array}$ \\
\hline Married Female & Interaction between marital status and respondent female & $\begin{array}{r}0.321 \\
(0.467) \\
\end{array}$ \\
\hline $\begin{array}{l}\text { Married Female } \\
\text { w/ kids }<18\end{array}$ & $\begin{array}{l}\text { Interaction between marital status, respondent female, and } \\
\text { residing with own minor children }\end{array}$ & $\begin{array}{c}0.184 \\
(0.387)\end{array}$ \\
\hline $\begin{array}{l}\text { Married Female } \\
\text { kids }<6\end{array}$ & $\begin{array}{l}\text { Interaction between marital status, respondent female, and } \\
\text { residing with own child who is under the age of six }\end{array}$ & $\begin{array}{c}0.093 \\
(0.291)\end{array}$ \\
\hline Non-US born & $\begin{array}{l}\text { One if respondent is U.S. citizen not born in the U.S. (omitted } \\
\text { category born in the U.S.) }\end{array}$ & $\begin{array}{r}0.065 \\
(0.247) \\
\end{array}$ \\
\hline Non-US Citizen & One if respondent is not a U.S. citizen & $\begin{array}{c}0.072 \\
(0.259)\end{array}$ \\
\hline
\end{tabular}

Notes: Standard deviations are shown in parentheses. 


\begin{tabular}{|c|c|c|}
\hline Variables & Variable Description & Means \\
\hline \multicolumn{3}{|c|}{ Neighborhood Level Variables } \\
\hline $\begin{array}{l}\text { Employment } \\
\text { Access }\end{array}$ & $\begin{array}{l}\text { gravity model based index using non-parametrically smoothed } \\
\text { estimates of commuting time between census tracts }\end{array}$ & $\begin{array}{c}1.051 \\
(0.067)\end{array}$ \\
\hline Percent Poverty & Percent of households in poverty within a census block group & $\begin{array}{c}0.051 \\
(0.065) \\
\end{array}$ \\
\hline $\begin{array}{l}\text { Percent College } \\
\text { Graduate }\end{array}$ & $\begin{array}{l}\text { Percent of prime age individuals (age 25-59) with a four year college } \\
\text { degree within a census block group }\end{array}$ & $\begin{array}{c}0.401 \\
(0.210)\end{array}$ \\
\hline $\begin{array}{l}\text { Housing Price } \\
\text { Residual }\end{array}$ & $\begin{array}{l}\text { Mean of housing price residual from metropolitan wide housing price } \\
\text { hedonic that controls for the three block group attributes listed above }\end{array}$ & $\begin{array}{c}0.005 \\
(0.067)\end{array}$ \\
\hline $\begin{array}{l}\text { Percent Minority } \\
\text { Disadvantage }\end{array}$ & $\begin{array}{l}\text { Percent of households in census block group headed by either an } \\
\text { African-American or Hispanic respondent }\end{array}$ & $\begin{array}{c}0.084 \\
(0.177)\end{array}$ \\
\hline $\begin{array}{l}\text { Percent Not } \\
\text { Born US }\end{array}$ & $\begin{array}{l}\text { Percent of prime age individuals in census block group who were not } \\
\text { born in the United States }\end{array}$ & $\begin{array}{c}0.069 \\
(0.061)\end{array}$ \\
\hline $\begin{array}{l}\text { Housing Stock } \\
\text { Index }\end{array}$ & $\begin{array}{l}\text { Housing stock index using mean housing stock attributes of each block } \\
\text { group using the hedonic price estimates on those mean attributes }\end{array}$ & $\begin{array}{c}0.215 \\
(0.167)\end{array}$ \\
\hline
\end{tabular}

Notes: Standard deviations are shown in parentheses. 


\begin{tabular}{|c|c|c|c|c|c|c|}
\hline \multirow[t]{2}{*}{ Variables } & \multicolumn{2}{|c|}{ Labor Force Participant } & \multicolumn{2}{|c|}{ Weeks Worked Last Year } & \multicolumn{2}{|c|}{ Weekly Hours Last Year } \\
\hline & OLS & $\begin{array}{c}\text { Final IV } \\
\text { Model }\end{array}$ & OLS & $\begin{array}{c}\text { Final IV } \\
\text { Model }\end{array}$ & OLS & $\begin{array}{c}\text { Final IV } \\
\text { Model }\end{array}$ \\
\hline Male & $\begin{array}{l}0.022 \\
(8.12)\end{array}$ & $\begin{array}{l}0.018 \\
(6.60)\end{array}$ & $\begin{array}{l}-0.549 \\
(5.39)\end{array}$ & $\begin{array}{l}-0.573 \\
(5.43)\end{array}$ & $\begin{array}{r}2.664 \\
(28.21) \\
\end{array}$ & $\begin{array}{r}2.626 \\
(27.10) \\
\end{array}$ \\
\hline Age 35-44 & $\begin{array}{l}0.001 \\
(0.36) \\
\end{array}$ & $\begin{array}{l}0.009 \\
(3.59) \\
\end{array}$ & $\begin{array}{l}0.721 \\
(8.77)\end{array}$ & $\begin{array}{r}1.014 \\
(10.95) \\
\end{array}$ & $\begin{array}{l}-0.534 \\
(6.81) \\
\end{array}$ & $\begin{array}{l}0.050 \\
(0.58) \\
\end{array}$ \\
\hline Age 45-59 & $\begin{array}{r}-0.053 \\
(22.05) \\
\end{array}$ & $\begin{array}{r}-0.040 \\
(11.77) \\
\end{array}$ & $\begin{array}{l}0.571 \\
(6.51)\end{array}$ & $\begin{array}{l}1.096 \\
(9.06) \\
\end{array}$ & $\begin{array}{r}-1.569 \\
(19.03) \\
\end{array}$ & $\begin{array}{l}-0.578 \\
(5.63) \\
\end{array}$ \\
\hline Black & $\begin{array}{l}0.031 \\
(5.90) \\
\end{array}$ & $\begin{array}{r}0.098 \\
(10.70) \\
\end{array}$ & $\begin{array}{l}0.352 \\
(1.94)\end{array}$ & $\begin{array}{l}-0.018 \\
(0.06) \\
\end{array}$ & $\begin{array}{l}0.707 \\
(4.45) \\
\end{array}$ & $\begin{array}{l}-1.266 \\
(4.68) \\
\end{array}$ \\
\hline Hispanic & $\begin{array}{l}-0.010 \\
(1.43)\end{array}$ & $\begin{array}{l}0.034 \\
(3.74)\end{array}$ & $\begin{array}{l}-0.365 \\
(-1.48)\end{array}$ & $\begin{array}{l}-0.670 \\
(-2.12)\end{array}$ & $\begin{array}{l}0.151 \\
(0.65)\end{array}$ & $\begin{array}{l}-1.423 \\
(-4.83)\end{array}$ \\
\hline Asian & $\begin{array}{l}-0.041 \\
(-4.55)\end{array}$ & $\begin{array}{l}-0.028 \\
(-3.05)\end{array}$ & $\begin{array}{l}-0.042 \\
(-0.17)\end{array}$ & $\begin{array}{l}-0.093 \\
(-0.35)\end{array}$ & $\begin{array}{l}0.611 \\
(2.31)\end{array}$ & $\begin{array}{l}-0.074 \\
(-0.28)\end{array}$ \\
\hline No High School & $\begin{array}{r}-0.087 \\
(-20.44)\end{array}$ & $\begin{array}{r}-0.076 \\
(-16.14)\end{array}$ & $\begin{array}{l}-1.271 \\
(-8.52)\end{array}$ & $\begin{array}{l}-1.535 \\
(-9.02)\end{array}$ & $\begin{array}{l}0.010 \\
(0.08)\end{array}$ & $\begin{array}{l}-0.799 \\
(-5.85)\end{array}$ \\
\hline Some college & $\begin{array}{r}0.052 \\
(20.69)\end{array}$ & $\begin{array}{r}0.054 \\
(17.43)\end{array}$ & $\begin{array}{l}0.580 \\
(6.58)\end{array}$ & $\begin{array}{l}1.023 \\
(9.06)\end{array}$ & $\begin{array}{l}0.411 \\
(5.04)\end{array}$ & $\begin{array}{r}1.262 \\
(12.31)\end{array}$ \\
\hline College & $\begin{array}{r}0.082 \\
(33.70)\end{array}$ & $\begin{array}{r}0.097 \\
(14.28)\end{array}$ & $\begin{array}{l}0.672 \\
(7.90)\end{array}$ & $\begin{array}{l}1.989 \\
(8.12)\end{array}$ & $\begin{array}{r}1.874 \\
(23.01\end{array}$ & $\begin{array}{r}4.025 \\
(17.89)\end{array}$ \\
\hline $\begin{array}{l}\text { Single } \\
\text { Independent }\end{array}$ & $\begin{array}{r}-0.035 \\
(12.34)\end{array}$ & $\begin{array}{l}-0.039 \\
(8.74)\end{array}$ & $\begin{array}{l}-1.253 \\
(11.43)\end{array}$ & $\begin{array}{l}-1.516 \\
(9.20)\end{array}$ & $\begin{array}{r}-1.627 \\
(13.96)\end{array}$ & $\begin{array}{r}-2.611 \\
(16.49) \\
\end{array}$ \\
\hline Single parent & $\begin{array}{r}-0.060 \\
(16.56) \\
\end{array}$ & $\begin{array}{r}-0.049 \\
(11.10) \\
\end{array}$ & $\begin{array}{r}-2.563 \\
(17.26) \\
\end{array}$ & $\begin{array}{r}-2.565 \\
(14.50) \\
\end{array}$ & $\begin{array}{r}-3.595 \\
(28.23) \\
\end{array}$ & $\begin{array}{r}-3.751 \\
(25.58) \\
\end{array}$ \\
\hline Single w/ family & $\begin{array}{r}-0.148 \\
(25.83) \\
\end{array}$ & $\begin{array}{r}-0.126 \\
(20.97) \\
\end{array}$ & $\begin{array}{r}-3.443 \\
(17.66) \\
\end{array}$ & $\begin{array}{r}-3.446 \\
(16.63) \\
\end{array}$ & $\begin{array}{r}-4.082 \\
(22.54) \\
\end{array}$ & $\begin{array}{r}-4.517 \\
(23.50) \\
\end{array}$ \\
\hline $\begin{array}{l}\text { Married w/ } \\
6<=\text { kids }<18\end{array}$ & $\begin{array}{l}0.015 \\
(6.34) \\
\end{array}$ & $\begin{array}{l}0.023 \\
(8.09) \\
\end{array}$ & $\begin{array}{l}0.581 \\
(6.14)\end{array}$ & $\begin{array}{l}0.788 \\
(7.49) \\
\end{array}$ & $\begin{array}{l}1.068 \\
(9.70)\end{array}$ & $\begin{array}{r}1.564 \\
(13.18) \\
\end{array}$ \\
\hline $\begin{array}{l}\text { Married w/ } \\
\text { kids }<6\end{array}$ & $\begin{array}{l}-0.003 \\
(1.15) \\
\end{array}$ & $\begin{array}{l}0.006 \\
(2.36) \\
\end{array}$ & $\begin{array}{l}0.771 \\
(7.89)\end{array}$ & $\begin{array}{l}0.945 \\
(8.89) \\
\end{array}$ & $\begin{array}{l}1.072 \\
(9.57)\end{array}$ & $\begin{array}{r}1.465 \\
(12.17) \\
\end{array}$ \\
\hline Married Female & $\begin{array}{r}-0.117 \\
(27.77)\end{array}$ & $\begin{array}{c}-0.118 \\
(27.69)\end{array}$ & $\begin{array}{r}-2.650 \\
(17.99)\end{array}$ & $\begin{array}{l}-2.543 \\
(17.01\end{array}$ & $\begin{array}{r}-4.506 \\
(30.99)\end{array}$ & $\begin{array}{r}-4.363 \\
(29.47)\end{array}$ \\
\hline $\begin{array}{l}\text { Married Female } \\
\text { w/ kids }<18\end{array}$ & $\begin{array}{r}-0.059 \\
(12.20) \\
\end{array}$ & $\begin{array}{r}-0.059 \\
(12.10) \\
\end{array}$ & $\begin{array}{l}-3.565 \\
(20.65) \\
\end{array}$ & $\begin{array}{r}-3.518 \\
(20.34)\end{array}$ & $\begin{array}{r}-6.551 \\
(36.33) \\
\end{array}$ & $\begin{array}{l}-6.485 \\
(3.00)\end{array}$ \\
\hline $\begin{array}{l}\text { Married Female } \\
\text { kids }<6\end{array}$ & $\begin{array}{r}-0.162 \\
(29.24) \\
\end{array}$ & $\begin{array}{r}-0.162 \\
(29.11) \\
\end{array}$ & $\begin{array}{r}-3.108 \\
(14.49) \\
\end{array}$ & $\begin{array}{r}-3.167 \\
(14.72) \\
\end{array}$ & $\begin{array}{r}-2.604 \\
(12.25) \\
\end{array}$ & $\begin{array}{r}-2.696 \\
(12.68) \\
\end{array}$ \\
\hline Non-US born & $\begin{array}{l}0.017 \\
(4.12) \\
\end{array}$ & $\begin{array}{l}0.013 \\
(2.90) \\
\end{array}$ & $\begin{array}{l}0.513 \\
(3.63) \\
\end{array}$ & $\begin{array}{r}0.40 \\
(2.53) \\
\end{array}$ & $\begin{array}{l}0.971 \\
(6.83) \\
\end{array}$ & $\begin{array}{l}0.583 \\
(3.77) \\
\end{array}$ \\
\hline Non-US Citizen & $\begin{array}{l}-0.020 \\
(3.91)\end{array}$ & $\begin{array}{l}-0.034 \\
(6.00)\end{array}$ & $\begin{array}{l}-1.857 \\
(10.66)\end{array}$ & $\begin{array}{r}-2.082 \\
(10.15) \\
\end{array}$ & $\begin{array}{l}0.309 \\
(1.95)\end{array}$ & $\begin{array}{l}-0.472 \\
(2.59) \\
\end{array}$ \\
\hline $\begin{array}{l}\text { Employment } \\
\text { Access }\end{array}$ & $\begin{array}{l}0.006 \\
(0.32)\end{array}$ & $\begin{array}{l}0.308 \\
(2.02)\end{array}$ & $\begin{array}{l}1.769 \\
(2.83)\end{array}$ & $\begin{array}{l}19.156 \\
(3.41)\end{array}$ & $\begin{array}{l}-1.501 \\
(2.68)\end{array}$ & $\begin{array}{l}36.068 \\
(7.42)\end{array}$ \\
\hline Percent Poverty & $\begin{array}{r}-0.528 \\
(20.62)\end{array}$ & $\begin{array}{l}-1.055 \\
(8.29)\end{array}$ & $\begin{array}{l}-11.176 \\
(15.03)\end{array}$ & $\begin{array}{c}-14.709 \\
(3.18)\end{array}$ & $\begin{array}{l}-3.550 \\
(5.14)\end{array}$ & $\begin{array}{l}6.027 \\
(1.52)\end{array}$ \\
\hline $\begin{array}{l}\text { Percent College } \\
\text { Graduate }\end{array}$ & $\begin{array}{r}-0.099 \\
(15.01) \\
\end{array}$ & $\begin{array}{l}-0.434 \\
(9.71)\end{array}$ & $\begin{array}{r}-2.397 \\
(12.26)\end{array}$ & $\begin{array}{c}-13.929 \\
(8.62) \\
\end{array}$ & $\begin{array}{l}1.264 \\
(6.11) \\
\end{array}$ & $\begin{array}{c}-17.186 \\
(11.93)\end{array}$ \\
\hline $\begin{array}{l}\text { Housing Price } \\
\text { Residual }\end{array}$ & & $\begin{array}{l}0.514 \\
(9.48) \\
\end{array}$ & & $\begin{array}{l}7.270 \\
(3.76) \\
\end{array}$ & & $\begin{array}{l}11.685 \\
(7.33) \\
\end{array}$ \\
\hline
\end{tabular}


Notes: The first, third and fifth columns contain OLS estimates with standard errors clustered at the census block group. The second, fourth, and sixth columns contain the estimates from the multi-stage instrumental variables analysis where averages for cells of observationally equivalent individuals are used as instruments for neighborhood attributes including the housing price residual and standard errors are clustered at the cell. T-statistics are shown in parentheses. 


\begin{tabular}{|c|c|c|c|c|c|c|}
\hline & \multicolumn{2}{|c|}{ Labor Force Participant } & \multicolumn{2}{|c|}{ Weeks Worked Last Year } & \multicolumn{2}{|c|}{ Weekly Hours Last Yea } \\
\hline & OLS & $\begin{array}{c}\text { Final IV } \\
\text { Model }\end{array}$ & OLS & $\begin{array}{c}\text { Final IV } \\
\text { Model }\end{array}$ & OLS & $\begin{array}{c}\text { Final IV } \\
\text { Model }\end{array}$ \\
\hline \multicolumn{7}{|c|}{ Full Sample } \\
\hline $\begin{array}{l}\text { Employment } \\
\text { Access }\end{array}$ & $\begin{array}{l}0.006 \\
(0.32) \\
\end{array}$ & $\begin{array}{l}0.308 \\
(2.02) \\
\end{array}$ & $\begin{array}{l}1.769 \\
(2.83) \\
\end{array}$ & $\begin{array}{l}19.156 \\
(3.41) \\
\end{array}$ & $\begin{array}{l}-1.501 \\
(2.68) \\
\end{array}$ & $\begin{array}{l}36.068 \\
(7.42) \\
\end{array}$ \\
\hline Percent Poverty & $\begin{array}{r}-0.528 \\
(20.62) \\
\end{array}$ & $\begin{array}{l}-1.055 \\
(8.29) \\
\end{array}$ & $\begin{array}{l}-11.176 \\
(15.03) \\
\end{array}$ & $\begin{array}{c}-14.709 \\
(3.18) \\
\end{array}$ & $\begin{array}{l}-3.550 \\
(5.14) \\
\end{array}$ & $\begin{array}{l}6.027 \\
(1.52) \\
\end{array}$ \\
\hline $\begin{array}{l}\text { Percent College } \\
\text { Graduate }\end{array}$ & $\begin{array}{l}-0.099 \\
(15.01\end{array}$ & $\begin{array}{l}-0.434 \\
(9.71)\end{array}$ & $\begin{array}{r}-2.397 \\
(12.26)\end{array}$ & $\begin{array}{c}-13.929 \\
(8.62)\end{array}$ & $\begin{array}{l}1.264 \\
(6.11)\end{array}$ & $\begin{array}{c}-17.186 \\
(11.93)\end{array}$ \\
\hline $\begin{array}{l}\text { Housing Price } \\
\text { Residual }\end{array}$ & & $\begin{array}{l}0.514 \\
(9.48)\end{array}$ & & $\begin{array}{l}7.270 \\
(3.76)\end{array}$ & & $\begin{array}{l}11.685 \\
(7.33) \\
\end{array}$ \\
\hline \multicolumn{7}{|c|}{ Sample After Dropping All Respondents with Degrees from Four Year Colleges } \\
\hline $\begin{array}{l}\text { Employment } \\
\text { Access }\end{array}$ & $\begin{array}{c}-0.004 \\
(0.19) \\
\end{array}$ & $\begin{array}{l}0.424 \\
(2.08) \\
\end{array}$ & $\begin{array}{l}2.616 \\
(3.82)\end{array}$ & $\begin{array}{l}17.239 \\
(2.37) \\
\end{array}$ & $\begin{array}{l}-3.901 \\
(6.00) \\
\end{array}$ & $\begin{array}{l}44.459 \\
(7.42) \\
\end{array}$ \\
\hline Percent Poverty & $\begin{array}{c}-0.578 \\
(19.75) \\
\end{array}$ & $\begin{array}{l}-1.203 \\
(7.66) \\
\end{array}$ & $\begin{array}{l}-10.010 \\
(11.52) \\
\end{array}$ & $\begin{array}{c}-11.284 \\
(2.01 \\
\end{array}$ & $\begin{array}{l}-3.020 \\
(4.01 \\
\end{array}$ & $\begin{array}{l}-0.160 \\
(0.03)\end{array}$ \\
\hline $\begin{array}{l}\text { Percent College } \\
\text { Graduate }\end{array}$ & $\begin{array}{r}-0.092 \\
(10.37)\end{array}$ & $\begin{array}{l}-0.225 \\
(2.94)\end{array}$ & $\begin{array}{l}-1.671 \\
(6.26)\end{array}$ & $\begin{array}{c}-14.480 \\
(5.39)\end{array}$ & $\begin{array}{l}-0.403 \\
(1.56)\end{array}$ & $\begin{array}{c}-16.394 \\
(7.39)\end{array}$ \\
\hline $\begin{array}{l}\text { Housing Price } \\
\text { Residual }\end{array}$ & & $\begin{array}{l}0.522 \\
(7.78)\end{array}$ & & $\begin{array}{l}11.163 \\
(4.58)\end{array}$ & & $\begin{array}{l}11.468 \\
(5.90)\end{array}$ \\
\hline \multicolumn{7}{|c|}{ Sample After Dropping All Respondents with Two or More Years of College } \\
\hline $\begin{array}{l}\text { Employment } \\
\text { Access }\end{array}$ & $\begin{array}{l}-0.044 \\
(1.59)\end{array}$ & $\begin{array}{l}0.704 \\
(2.28)\end{array}$ & $\begin{array}{l}3.457 \\
(3.82)\end{array}$ & $\begin{array}{l}14.367 \\
(1.30)\end{array}$ & $\begin{array}{l}-4.701 \\
(5.95)\end{array}$ & $\begin{array}{l}32.041 \\
(3.59)\end{array}$ \\
\hline Percent Poverty & $\begin{array}{r}-0.604 \\
(17.59)\end{array}$ & $\begin{array}{l}-1.533 \\
(7.00)\end{array}$ & $\begin{array}{l}-9.034 \\
(7.97)\end{array}$ & $\begin{array}{c}-20.073 \\
(2.53)\end{array}$ & $\begin{array}{l}-2.104 \\
(2.41)\end{array}$ & $\begin{array}{l}-7.825 \\
(1.19)\end{array}$ \\
\hline $\begin{array}{l}\text { Percent College } \\
\text { Graduate }\end{array}$ & $\begin{array}{l}-0.063 \\
(4.96)\end{array}$ & $\begin{array}{l}-0.188 \\
(1.38)\end{array}$ & $\begin{array}{l}-0.635 \\
(1.65)\end{array}$ & $\begin{array}{c}-16.547 \\
(3.47)\end{array}$ & $\begin{array}{l}0.156 \\
(0.44)\end{array}$ & $\begin{array}{l}-8.290 \\
(2.10)\end{array}$ \\
\hline $\begin{array}{l}\text { Housing Price } \\
\text { Residual }\end{array}$ & & $\begin{array}{l}0.480 \\
(5.57)\end{array}$ & & $\begin{array}{l}12.046 \\
(3.74)\end{array}$ & & $\begin{array}{l}7.121 \\
(2.88)\end{array}$ \\
\hline
\end{tabular}

Notes: The first panel replicates results from Table 2 while the next two panels present results for subsamples that omit individuals with four year college degrees or two or more years of college, respectively. The first, third and fifth columns contain OLS estimates with standard errors clustered at the census block group. The second, fourth, and sixth columns contain estimates for the multi-stage instrumental variables analysis with standard errors clustered at the cell. T-statistics are shown in parentheses. 


\begin{tabular}{|c|c|c|c|c|c|c|}
\hline & \multicolumn{2}{|c|}{$\begin{array}{c}\text { Labor Force } \\
\text { Participant }\end{array}$} & \multicolumn{2}{|c|}{ Weeks Worked Last Year } & \multicolumn{2}{|c|}{ Weekly Hours Last Year } \\
\hline & OLS & $\begin{array}{c}\text { Final IV } \\
\text { Model }\end{array}$ & OLS & $\begin{array}{c}\text { Final IV } \\
\text { Model }\end{array}$ & OLS & $\begin{array}{c}\text { Final IV } \\
\text { Model }\end{array}$ \\
\hline \multicolumn{7}{|c|}{ Full Sample } \\
\hline $\begin{array}{l}\text { Employment } \\
\text { Access }\end{array}$ & $\begin{array}{l}0.006 \\
(0.32)\end{array}$ & $\begin{array}{l}0.308 \\
(2.02)\end{array}$ & $\begin{array}{l}1.769 \\
(2.83)\end{array}$ & $\begin{array}{l}19.156 \\
(3.41)\end{array}$ & $\begin{array}{l}-1.501 \\
(2.68)\end{array}$ & $\begin{array}{l}36.068 \\
(7.42)\end{array}$ \\
\hline Percent Poverty & $\begin{array}{r}-0.528 \\
(20.62) \\
\end{array}$ & $\begin{array}{l}-1.055 \\
(8.29) \\
\end{array}$ & $\begin{array}{l}-11.176 \\
(15.03) \\
\end{array}$ & $\begin{array}{c}-14.709 \\
(3.18) \\
\end{array}$ & $\begin{array}{l}-3.550 \\
(5.14) \\
\end{array}$ & $\begin{array}{l}6.027 \\
(1.52) \\
\end{array}$ \\
\hline $\begin{array}{l}\text { Percent College } \\
\text { Graduate }\end{array}$ & $\begin{array}{c}-0.099 \\
(15.01 \\
\end{array}$ & $\begin{array}{l}-0.434 \\
(9.71) \\
\end{array}$ & $\begin{array}{r}-2.397 \\
(12.26) \\
\end{array}$ & $\begin{array}{c}-13.929 \\
(8.62) \\
\end{array}$ & $\begin{array}{l}1.264 \\
(6.11) \\
\end{array}$ & $\begin{array}{l}-17.186 \\
(11.93) \\
\end{array}$ \\
\hline $\begin{array}{l}\text { Housing Price } \\
\text { Residual }\end{array}$ & & $\begin{array}{l}0.514 \\
(9.48)\end{array}$ & & $\begin{array}{l}7.270 \\
(3.76) \\
\end{array}$ & & $\begin{array}{l}11.685 \\
(7.33)\end{array}$ \\
\hline \multicolumn{7}{|c|}{ Sample After Dropping All White Collar Employees } \\
\hline $\begin{array}{l}\text { Employment } \\
\text { Access }\end{array}$ & $\begin{array}{l}0.033 \\
(2.01\end{array}$ & $\begin{array}{l}0.599 \\
(3.92)\end{array}$ & $\begin{array}{l}1.833 \\
(2.59)\end{array}$ & $\begin{array}{l}19.695 \\
(2.85)\end{array}$ & $\begin{array}{l}-3.140 \\
(4.76)\end{array}$ & $\begin{array}{l}40.048 \\
(7.05)\end{array}$ \\
\hline Percent Poverty & $\begin{array}{c}-0.304 \\
(14.16) \\
\end{array}$ & $\begin{array}{l}-0.715 \\
(5.71) \\
\end{array}$ & $\begin{array}{r}-11.077 \\
(12.42) \\
\end{array}$ & $\begin{array}{c}-11.635 \\
(2.07) \\
\end{array}$ & $\begin{array}{l}-3.592 \\
(4.58) \\
\end{array}$ & $\begin{array}{l}4.826 \\
(1.05) \\
\end{array}$ \\
\hline $\begin{array}{l}\text { Percent College } \\
\text { Graduate }\end{array}$ & $\begin{array}{l}-0.061 \\
(9.22) \\
\end{array}$ & $\begin{array}{l}-0.225 \\
(4.41) \\
\end{array}$ & $\begin{array}{l}-2.349 \\
(9.04)\end{array}$ & $\begin{array}{c}-13.342 \\
(6.12) \\
\end{array}$ & $\begin{array}{l}-0.108 \\
(0.43) \\
\end{array}$ & $\begin{array}{c}-15.812 \\
(8.57) \\
\end{array}$ \\
\hline $\begin{array}{l}\text { Housing Price } \\
\text { Residual }\end{array}$ & & $\begin{array}{l}0.288 \\
(5.56)\end{array}$ & & $\begin{array}{l}10.563 \\
(4.56)\end{array}$ & & $\begin{array}{l}10.586 \\
(5.79)\end{array}$ \\
\hline
\end{tabular}

Notes: The first panel replicates results from Table 2 while the next panel presents results for a subsample that omits individuals in occupations classified as managerial and professional specialty occupations (000-199). The first, third and fifth columns contain OLS estimates with standard errors clustered at the census block group. The second, fourth, and sixth columns contain the estimates for the multi-stage instrumental variables analysis with standard errors clustered at the cell. T-statistics are shown in parentheses. 


\begin{tabular}{|c|c|c|c|c|c|c|}
\hline & \multicolumn{2}{|c|}{$\begin{array}{c}\text { Labor Force } \\
\text { Participant }\end{array}$} & \multicolumn{2}{|c|}{ Weeks Worked Last Year } & \multicolumn{2}{|c|}{ Weekly Hours Last Year } \\
\hline & OLS & $\begin{array}{c}\text { Final IV } \\
\text { Model }\end{array}$ & OLS & $\begin{array}{c}\text { Final IV } \\
\text { Model } \\
\end{array}$ & OLS & $\begin{array}{c}\text { Final IV } \\
\text { Model } \\
\end{array}$ \\
\hline \multicolumn{7}{|c|}{ Full Sample } \\
\hline $\begin{array}{l}\text { Employment } \\
\text { Access }\end{array}$ & $\begin{array}{l}0.006 \\
(0.32)\end{array}$ & $\begin{array}{l}0.308 \\
(2.02)\end{array}$ & $\begin{array}{l}1.769 \\
(2.83)\end{array}$ & $\begin{array}{l}19.156 \\
(3.41)\end{array}$ & $\begin{array}{l}-1.501 \\
(2.68)\end{array}$ & $\begin{array}{l}36.068 \\
(7.42)\end{array}$ \\
\hline Percent Poverty & $\begin{array}{r}-0.528 \\
(20.62)\end{array}$ & $\begin{array}{l}-1.055 \\
(8.29)\end{array}$ & $\begin{array}{l}-11.176 \\
(15.03)\end{array}$ & $\begin{array}{c}-14.709 \\
(3.18) \\
\end{array}$ & $\begin{array}{l}-3.550 \\
(5.14)\end{array}$ & $\begin{array}{l}6.027 \\
(1.52)\end{array}$ \\
\hline $\begin{array}{l}\text { Percent College } \\
\text { Graduate }\end{array}$ & $\begin{array}{l}-0.099 \\
(15.01 \\
\end{array}$ & $\begin{array}{l}-0.434 \\
(9.71)\end{array}$ & $\begin{array}{r}-2.397 \\
(12.26) \\
\end{array}$ & $\begin{array}{c}-13.929 \\
(8.62) \\
\end{array}$ & $\begin{array}{l}1.264 \\
(6.11)\end{array}$ & $\begin{array}{l}-17.186 \\
(11.93) \\
\end{array}$ \\
\hline $\begin{array}{l}\text { Housing Price } \\
\text { Residual }\end{array}$ & & $\begin{array}{l}0.514 \\
(9.48) \\
\end{array}$ & & $\begin{array}{l}7.270 \\
(3.76) \\
\end{array}$ & & $\begin{array}{l}11.685 \\
(7.33) \\
\end{array}$ \\
\hline \multicolumn{7}{|c|}{ Sample After Dropping All Married Women with Children } \\
\hline $\begin{array}{l}\text { Employment } \\
\text { Access }\end{array}$ & $\begin{array}{l}-0.023 \\
(1.23) \\
\end{array}$ & $\begin{array}{l}0.300 \\
(1.88)\end{array}$ & $\begin{array}{l}0.560 \\
(0.83)\end{array}$ & $\begin{array}{l}10.518 \\
(1.82)\end{array}$ & $\begin{array}{l}-2.464 \\
(4.36)\end{array}$ & $\begin{array}{l}14.477 \\
(2.82)\end{array}$ \\
\hline Percent Poverty & $\begin{array}{l}-0.548 \\
(21.49)\end{array}$ & $\begin{array}{l}-1.283 \\
(9.60)\end{array}$ & $\begin{array}{l}-11.728 \\
(14.178)\end{array}$ & $\begin{array}{c}-19.112 \\
(3.97) \\
\end{array}$ & $\begin{array}{l}-4.700 \\
(6.48)\end{array}$ & $\begin{array}{l}3.751 \\
(0.89)\end{array}$ \\
\hline $\begin{array}{l}\text { Percent College } \\
\text { Graduate }\end{array}$ & $\begin{array}{l}-0.075 \\
(11.61) \\
\end{array}$ & $\begin{array}{l}-0.582 \\
(12.45) \\
\end{array}$ & $\begin{array}{l}-2.180 \\
(10.72)\end{array}$ & $\begin{array}{c}-14.357 \\
(8.49) \\
\end{array}$ & $\begin{array}{l}1.747 \\
(8.29)\end{array}$ & $\begin{array}{c}-13.214 \\
(8.66) \\
\end{array}$ \\
\hline $\begin{array}{l}\text { Housing Price } \\
\text { Residual }\end{array}$ & & $\begin{array}{l}0.468 \\
(8.39)\end{array}$ & & $\begin{array}{l}4.176 \\
(2.12)\end{array}$ & & $\begin{array}{l}4.029 \\
(2.43)\end{array}$ \\
\hline \multicolumn{7}{|c|}{ Sample After Dropping All Married Women } \\
\hline $\begin{array}{l}\text { Employment } \\
\text { Access }\end{array}$ & $\begin{array}{r}-0.029 \\
(0.38)\end{array}$ & $\begin{array}{l}0.180 \\
(1.09)\end{array}$ & $\begin{array}{l}0.155 \\
(0.21)\end{array}$ & $\begin{array}{l}0.363 \\
(0.06)\end{array}$ & $\begin{array}{l}-3.068 \\
(5.00)\end{array}$ & $\begin{array}{l}-4.176 \\
(0.78)\end{array}$ \\
\hline Percent Poverty & $\begin{array}{l}-0.577 \\
(21.93)\end{array}$ & $\begin{array}{l}-1.349 \\
(9.64)\end{array}$ & $\begin{array}{l}-12.153 \\
(14.90)\end{array}$ & $\begin{array}{c}-10.489 \\
(2.07)\end{array}$ & $\begin{array}{l}-5.263 \\
(6.72)\end{array}$ & $\begin{array}{l}17.288 \\
(3.94)\end{array}$ \\
\hline $\begin{array}{l}\text { Percent College } \\
\text { Graduate }\end{array}$ & $\begin{array}{l}-0.049 \\
(7.65)\end{array}$ & $\begin{array}{l}-0.273 \\
(5.63)\end{array}$ & $\begin{array}{l}-1.853 \\
(8.80)\end{array}$ & $\begin{array}{l}-5.916 \\
(3.28)\end{array}$ & $\begin{array}{l}2.287 \\
(9.95)\end{array}$ & $\begin{array}{l}1.394 \\
(0.84)\end{array}$ \\
\hline $\begin{array}{l}\text { Housing Price } \\
\text { Residual }\end{array}$ & & $\begin{array}{l}0.473 \\
(7.98)\end{array}$ & & $\begin{array}{l}4.699 \\
(2.27)\end{array}$ & & $\begin{array}{l}4.680 \\
(2.71)\end{array}$ \\
\hline \multicolumn{7}{|c|}{ Sample After Dropping All Women } \\
\hline $\begin{array}{l}\text { Employment } \\
\text { Access }\end{array}$ & $\begin{array}{l}-0.053 \\
(2.83)\end{array}$ & $\begin{array}{l}-0.218 \\
(1.26)\end{array}$ & $\begin{array}{l}-0.812 \\
(1.12)\end{array}$ & $\begin{array}{l}-4.658 \\
(0.68)\end{array}$ & $\begin{array}{l}-4.036 \\
(5.82)\end{array}$ & $\begin{array}{c}-11.178 \\
(1.68)\end{array}$ \\
\hline Percent Poverty & $\begin{array}{l}-0.429 \\
(14.21)\end{array}$ & $\begin{array}{c}-0.290 \\
(2.01\end{array}$ & $\begin{array}{l}-12.042 \\
(12.45)\end{array}$ & $\begin{array}{c}-5.867 \\
(1.01\end{array}$ & $\begin{array}{l}-4.966 \\
(4.84)\end{array}$ & $\begin{array}{c}20.916 \\
(3.94)\end{array}$ \\
\hline $\begin{array}{l}\text { Percent College } \\
\text { Graduate }\end{array}$ & $\begin{array}{r}-0.037 \\
(5.17) \\
\end{array}$ & $\begin{array}{l}-0.017 \\
(0.33)\end{array}$ & $\begin{array}{l}-1.257 \\
(5.35) \\
\end{array}$ & $\begin{array}{l}-7.434 \\
(3.57) \\
\end{array}$ & $\begin{array}{c}3.131 \\
(11.43) \\
\end{array}$ & $\begin{array}{l}2.438 \\
(1.20)\end{array}$ \\
\hline $\begin{array}{l}\text { Housing Price } \\
\text { Residual }\end{array}$ & & $\begin{array}{l}0.073 \\
(1.01)\end{array}$ & & $\begin{array}{l}2.534 \\
(0.94)\end{array}$ & & $\begin{array}{l}-0.779 \\
(0.33)\end{array}$ \\
\hline
\end{tabular}

Notes: The first panel replicates results from Table 2 while the next three panels present results for subsamples that omit married women with children, married women, and all women from the sample, respectively. The first, third and fifth columns contain OLS estimates with standard errors clustered at the census block group. The second, fourth, and sixth columns contain the estimates for multi-stage instrumental variables analysis with standard errors are clustered at the cell. T-statistics are shown in parentheses. 


\begin{tabular}{|c|c|c|c|c|c|c|}
\hline Models & OLS & $\begin{array}{c}\text { Fixed } \\
\text { Effects } \\
\text { Second } \\
\text { Stage }\end{array}$ & $\begin{array}{c}\text { IV } \\
\text { Neighborhood } \\
\text { Controls }\end{array}$ & $\begin{array}{l}\text { IV with } \\
\text { Housing } \\
\text { Price } \\
\text { Residual }\end{array}$ & $\begin{array}{l}\text { IV for } \\
\text { Housing } \\
\text { Price } \\
\text { Residual }\end{array}$ & $\begin{array}{c}\text { Final IV } \\
\text { Model }\end{array}$ \\
\hline \multicolumn{7}{|c|}{ Labor Force Participant } \\
\hline $\begin{array}{l}\text { Employment } \\
\text { Access }\end{array}$ & $\begin{array}{l}0.006 \\
(0.32)\end{array}$ & $\begin{array}{l}0.027 \\
(1.28)\end{array}$ & $\begin{array}{l}0.620 \\
(4.18)\end{array}$ & $\begin{array}{r}0.601 \\
(4.05)\end{array}$ & $\begin{array}{l}1.461 \\
(8.93)\end{array}$ & $\begin{array}{l}0.308 \\
(2.02)\end{array}$ \\
\hline Percent Poverty & $\begin{array}{r}-0.528 \\
(20.62)\end{array}$ & $\begin{array}{l}-0.523 \\
(30.66) \\
\end{array}$ & $\begin{array}{r}-1.674 \\
(13.65)\end{array}$ & $\begin{array}{r}-1.665 \\
(13.52)\end{array}$ & $\begin{array}{r}-2.250 \\
(16.82) \\
\end{array}$ & $\begin{array}{l}-1.055 \\
(8.29)\end{array}$ \\
\hline $\begin{array}{l}\text { Percent College } \\
\text { Graduate }\end{array}$ & $\begin{array}{l}-0.099 \\
(15.01\end{array}$ & $\begin{array}{c}-0.091 \\
(14.02) \\
\end{array}$ & $\begin{array}{l}-0.251 \\
(6.30)\end{array}$ & $\begin{array}{l}-0.221 \\
(5.57)\end{array}$ & $\begin{array}{c}-0.866 \\
(12.36)\end{array}$ & $\begin{array}{l}-0.434 \\
(9.71)\end{array}$ \\
\hline $\begin{array}{l}\text { Housing Price } \\
\text { Residual }\end{array}$ & & & & $\begin{array}{l}-0.062 \\
(9.07) \\
\end{array}$ & $\begin{array}{r}0.696 \\
(11.68) \\
\end{array}$ & $\begin{array}{l}0.514 \\
(9.48)\end{array}$ \\
\hline \multicolumn{7}{|c|}{ Weeks Worked Last Year } \\
\hline $\begin{array}{l}\text { Employment } \\
\text { Access }\end{array}$ & $\begin{array}{l}-1.501 \\
(2.68) \\
\end{array}$ & $\begin{array}{l}1.011 \\
(0.84) \\
\end{array}$ & $\begin{array}{c}43.157 \\
(9.01 \\
\end{array}$ & $\begin{array}{c}43.568 \\
(9.10) \\
\end{array}$ & $\begin{array}{l}52.121 \\
(9.72) \\
\end{array}$ & $\begin{array}{l}36.068 \\
(7.42) \\
\end{array}$ \\
\hline Percent Poverty & $\begin{array}{l}-3.550 \\
(5.14) \\
\end{array}$ & $\begin{array}{l}-42.043 \\
(43.32) \\
\end{array}$ & $\begin{array}{l}-6.902 \\
(1.99) \\
\end{array}$ & $\begin{array}{l}-7.159 \\
(2.06) \\
\end{array}$ & $\begin{array}{c}-13.454 \\
(3.53) \\
\end{array}$ & $\begin{array}{l}6.027 \\
(1.52) \\
\end{array}$ \\
\hline $\begin{array}{l}\text { Percent College } \\
\text { Graduate }\end{array}$ & $\begin{array}{l}1.264 \\
(6.11) \\
\end{array}$ & $\begin{array}{l}1.251 \\
(3.40)\end{array}$ & $\begin{array}{c}-12.892 \\
(9.60) \\
\end{array}$ & $\begin{array}{r}-13.490 \\
(10.08) \\
\end{array}$ & $\begin{array}{c}-19.426 \\
(9.02) \\
\end{array}$ & $\begin{array}{r}-17.186 \\
(11.93) \\
\end{array}$ \\
\hline $\begin{array}{l}\text { Housing Price } \\
\text { Residual }\end{array}$ & & & & $\begin{array}{l}1.301 \\
(7.03) \\
\end{array}$ & $\begin{array}{l}7.243 \\
(3.86) \\
\end{array}$ & $\begin{array}{l}11.685 \\
(7.33) \\
\end{array}$ \\
\hline \multicolumn{7}{|c|}{ Weekly Hours Last Year } \\
\hline $\begin{array}{l}\text { Employment } \\
\text { Access }\end{array}$ & $\begin{array}{l}1.769 \\
(2.83) \\
\end{array}$ & $\begin{array}{l}-1.925 \\
(1.84) \\
\end{array}$ & $\begin{array}{r}23.570 \\
(4.29) \\
\end{array}$ & $\begin{array}{l}23.066 \\
(4.20) \\
\end{array}$ & $\begin{array}{l}31.185 \\
(5.10) \\
\end{array}$ & $\begin{array}{l}19.156 \\
(3.41) \\
\end{array}$ \\
\hline Percent Poverty & $\begin{array}{l}-11.176 \\
(15.03) \\
\end{array}$ & $\begin{array}{l}-32.24 \\
(37.98) \\
\end{array}$ & $\begin{array}{c}-22.723 \\
(5.36) \\
\end{array}$ & $\begin{array}{c}-22.413 \\
(5.28) \\
\end{array}$ & $\begin{array}{c}-28.302 \\
(5.90) \\
\end{array}$ & $\begin{array}{c}-14.709 \\
(3.18) \\
\end{array}$ \\
\hline $\begin{array}{l}\text { Percent College } \\
\text { Graduate }\end{array}$ & $\begin{array}{r}-2.397 \\
(12.26) \\
\end{array}$ & $\begin{array}{c}4.073 \\
(12.64) \\
\end{array}$ & $\begin{array}{c}-11.251 \\
(7.83) \\
\end{array}$ & $\begin{array}{c}-10.521 \\
(7.31) \\
\end{array}$ & $\begin{array}{l}-16.80 \\
(6.69) \\
\end{array}$ & $\begin{array}{c}-13.929 \\
(8.62) \\
\end{array}$ \\
\hline $\begin{array}{l}\text { Housing Price } \\
\text { Residual }\end{array}$ & & & & $\begin{array}{l}-1.601 \\
(8.70)\end{array}$ & $\begin{array}{l}6.147 \\
(2.87) \\
\end{array}$ & $\begin{array}{l}7.270 \\
(3.76) \\
\end{array}$ \\
\hline
\end{tabular}

Notes: The first and second columns contain OLS and block group fixed effect estimates with standard errors clustered at the census block group. The third column contains estimates for a simple instrumental variable model where the three neighborhood variables are predicted using means from cells of observationally equivalent individuals. The final three columns add the housing price residual from a simple, OLS housing price hedonic as a control, instrument for that residual based on cell means, and finally instrument for a residual arising from using IV in the housing price model. Standard errors are clustered at the cell for IV estimates. The results for the three dependent variables are presented in the three panels, and T-statistics are shown in parentheses. 


\begin{tabular}{|c|c|c|c|c|c|c|}
\hline Models & $\begin{array}{l}\text { Housing } \\
\text { Price } \\
\text { Residual } \\
\text { Only }\end{array}$ & Poverty & $\begin{array}{c}\text { Poverty and } \\
\text { Employment } \\
\text { Access }\end{array}$ & $\begin{array}{c}\text { Plus } \\
\text { Percent } \\
\text { College } \\
\text { Graduate }\end{array}$ & $\begin{array}{c}\text { Plus Percent } \\
\text { Minority } \\
\text { Disadvantaged }\end{array}$ & $\begin{array}{c}\text { Plus } \\
\text { Percent not } \\
\text { born in } \\
\text { U.S. }\end{array}$ \\
\hline \multicolumn{7}{|c|}{ Labor Force Participant } \\
\hline $\begin{array}{l}\text { Employment } \\
\text { Access }\end{array}$ & & & $\begin{array}{l}-0.166 \\
(1.11)\end{array}$ & $\begin{array}{l}0.308 \\
(2.02)\end{array}$ & $\begin{array}{l}0.226 \\
(1.47)\end{array}$ & $\begin{array}{l}-0.039 \\
(0.24)\end{array}$ \\
\hline Percent Poverty & & $\begin{array}{r}-1.226 \\
(11.81)\end{array}$ & $\begin{array}{l}-0.905 \\
(7.11)\end{array}$ & $\begin{array}{l}-1.055 \\
(8.29)\end{array}$ & $\begin{array}{l}-1.435 \\
(9.27)\end{array}$ & $\begin{array}{r}-1.772 \\
(11.19)\end{array}$ \\
\hline $\begin{array}{l}\text { Percent College } \\
\text { Graduate }\end{array}$ & & & & $\begin{array}{l}-0.434 \\
(9.71)\end{array}$ & $\begin{array}{l}-0.435 \\
(9.68)\end{array}$ & $\begin{array}{l}-0.361 \\
(8.12)\end{array}$ \\
\hline $\begin{array}{l}\text { Percent Minority } \\
\text { Disadvantage }\end{array}$ & & & & & $\begin{array}{l}0.186 \\
(4.43) \\
\end{array}$ & $\begin{array}{l}0.053 \\
(1.22) \\
\end{array}$ \\
\hline $\begin{array}{l}\text { Percent Not Born } \\
\text { US }\end{array}$ & & & & & & $\begin{array}{l}1.268 \\
(7.49)\end{array}$ \\
\hline $\begin{array}{l}\text { Housing Price } \\
\text { Residual }\end{array}$ & $\begin{array}{l}0.308 \\
(9.90)\end{array}$ & $\begin{array}{l}0.106 \\
(3.45)\end{array}$ & $\begin{array}{l}0.259 \\
(6.24)\end{array}$ & $\begin{array}{l}0.514 \\
(9.48)\end{array}$ & $\begin{array}{r}0.586 \\
(10.59) \\
\end{array}$ & $\begin{array}{l}0.526 \\
(9.27)\end{array}$ \\
\hline \multicolumn{7}{|c|}{ Weeks Worked Last Year } \\
\hline $\begin{array}{l}\text { Employment } \\
\text { Access }\end{array}$ & & & $\begin{array}{l}3.779 \\
(0.71) \\
\end{array}$ & $\begin{array}{l}19.156 \\
(3.41) \\
\end{array}$ & $\begin{array}{l}17.570 \\
(3.11) \\
\end{array}$ & $\begin{array}{l}12.808 \\
(2.20) \\
\end{array}$ \\
\hline Percent Poverty & & $\begin{array}{c}-11.556 \\
(3.31) \\
\end{array}$ & $\begin{array}{l}-9.154 \\
(2.00) \\
\end{array}$ & $\begin{array}{c}-14.709 \\
(3.18) \\
\end{array}$ & $\begin{array}{c}-23.654 \\
(4.31) \\
\end{array}$ & $\begin{array}{c}-28.957 \\
(5.21) \\
\end{array}$ \\
\hline $\begin{array}{l}\text { Percent College } \\
\text { Graduate }\end{array}$ & & & & $\begin{array}{c}-13.929 \\
(8.62) \\
\end{array}$ & $\begin{array}{c}-13.863 \\
(8.58) \\
\end{array}$ & $\begin{array}{c}-12.735 \\
(7.85) \\
\end{array}$ \\
\hline $\begin{array}{l}\text { Percent Minority } \\
\text { Disadvantage }\end{array}$ & & & & & $\begin{array}{r}4.20 \\
(3.01 \\
\end{array}$ & $\begin{array}{l}1.892 \\
(1.28)\end{array}$ \\
\hline $\begin{array}{l}\text { Percent Not } \\
\text { Born US }\end{array}$ & & & & & & $\begin{array}{l}21.906 \\
(4.24) \\
\end{array}$ \\
\hline $\begin{array}{l}\text { Housing Price } \\
\text { Residual }\end{array}$ & $\begin{array}{l}-1.577 \\
(1.60)\end{array}$ & $\begin{array}{l}-3.217 \\
(3.11)\end{array}$ & $\begin{array}{l}0.303 \\
(0.21)\end{array}$ & $\begin{array}{l}7.270 \\
(3.76)\end{array}$ & $\begin{array}{l}8.628 \\
(4.38)\end{array}$ & $\begin{array}{l}7.794 \\
(3.88)\end{array}$ \\
\hline \multicolumn{7}{|c|}{ Weekly Hours Last Year } \\
\hline $\begin{array}{l}\text { Employment } \\
\text { Access }\end{array}$ & & & $\begin{array}{l}20.378 \\
(4.47) \\
\end{array}$ & $\begin{array}{l}36.068 \\
(7.42) \\
\end{array}$ & $\begin{array}{l}34.843 \\
(7.14) \\
\end{array}$ & $\begin{array}{l}28.495 \\
(5.64) \\
\end{array}$ \\
\hline Percent Poverty & & $\begin{array}{l}13.136 \\
(4.39) \\
\end{array}$ & $\begin{array}{l}8.823 \\
(2.25)\end{array}$ & $\begin{array}{l}6.027 \\
(1.52)\end{array}$ & $\begin{array}{l}-0.474 \\
(0.10)\end{array}$ & $\begin{array}{l}-7.005 \\
(1.43)\end{array}$ \\
\hline $\begin{array}{l}\text { Percent College } \\
\text { Graduate }\end{array}$ & & & & $\begin{array}{l}-17.186 \\
(11.93)\end{array}$ & $\begin{array}{l}-17.202 \\
(11.88)\end{array}$ & $\begin{array}{l}-15.898 \\
(10.97)\end{array}$ \\
\hline $\begin{array}{l}\text { Percent Minority } \\
\text { Disadvantage }\end{array}$ & & & & & $\begin{array}{l}2.995 \\
(2.35)\end{array}$ & $\begin{array}{l}0.094 \\
(0.07)\end{array}$ \\
\hline $\begin{array}{l}\text { Percent Not } \\
\text { Born US }\end{array}$ & & & & & & $\begin{array}{r}28.035 \\
(5.89)\end{array}$ \\
\hline $\begin{array}{l}\text { Housing Price } \\
\text { Residual }\end{array}$ & $\begin{array}{r}-3.830 \\
(4.19) \\
\end{array}$ & $\begin{array}{l}-1.890 \\
(1.86) \\
\end{array}$ & $\begin{array}{l}0.454 \\
(0.36) \\
\end{array}$ & $\begin{array}{l}11.685 \\
(7.33) \\
\end{array}$ & $\begin{array}{l}12.837 \\
(7.84) \\
\end{array}$ & $\begin{array}{l}12.136 \\
(7.16)\end{array}$ \\
\hline
\end{tabular}


Notes: The estimation results are based on the final IV model used in Tables 2 through 5. Column 1 presents a model that only controls for the housing price residual, and columns 2 and 3 present results including neighborhood poverty levels plus employment access for column 3 . The next three columns add neighborhood controls for share four year college graduate, share African-American or Hispanic, and share not born in the U.S. The housing price residual in each model only conditions on the neighborhood controls used for that particular model. The three dependent variables are presented in the three panels, and T-statistics are shown in parentheses. 


\begin{tabular}{|l|c|c|c|c|c|c|}
\hline Table 8: Relationship between Neighborhood and Capital Income \\
\hline \multirow{2}{*}{ Variables } & \multicolumn{2}{c|}{$\begin{array}{c}\text { Positive Capital } \\
\text { Income }\end{array}$} & \multicolumn{2}{c|}{$\begin{array}{c}\text { Capital Income Above } \\
\text { \$1,000 }\end{array}$} & \multicolumn{2}{c|}{$\begin{array}{c}\text { Capital Income Above } \\
\text { \$3,000 }\end{array}$} \\
\cline { 2 - 7 } & OLS & $\begin{array}{c}\text { Final IV } \\
\text { Model }\end{array}$ & OLS & $\begin{array}{c}\text { Final IV } \\
\text { Model }\end{array}$ & OLS & $\begin{array}{c}\text { Final IV } \\
\text { Model }\end{array}$ \\
\hline Employment & 0.143 & 0.079 & 0.159 & 0.034 & 0.158 & 0.045 \\
Access & $(3.82)$ & $(0.41)$ & $(4.70)$ & $(0.19)$ & $(5.19)$ & $(0.26)$ \\
\hline Percent Poverty & -0.127 & -0.058 & -0.042 & 0.065 & 0.012 & 0.152 \\
& $(3.33)$ & $(0.38)$ & $(1.22)$ & $(0.46)$ & $(0.38)$ & $(1.10)$ \\
\hline Percent College & 0.084 & 0.051 & 0.043 & .0002 & 0.026 & -0.034 \\
Graduate & $(6.40)$ & $(0.88)$ & $(3.63)$ & $(0.01$ & $(2.40)$ & $(0.64)$ \\
\hline Housing Price & & -0.004 & & 0.038 & & 0.058 \\
Residual & & $(0.06)$ & & $(0.64)$ & & $(1.01$ \\
\hline
\end{tabular}

Notes: This tables presents estimates for whether the individual have positive capital income or not, capital income above $\$ 1000$ per year or not, and capital income above $\$ 3,000$ per year. The first, third and fifth columns contain OLS estimates with standard errors clustered at the census block group. The second, fourth, and sixth columns contain estimates for the multi-stage instrumental variables analysis with standard errors clustered at the cell. T-statistics are shown in parentheses. 


\begin{tabular}{|c|c|c|c|c|c|c|}
\hline \multicolumn{7}{|c|}{ Core Labor Market Outcomes } \\
\hline & \multicolumn{2}{|c|}{ Labor Force Participant } & \multicolumn{2}{|c|}{ Weeks Worked Last Year } & \multicolumn{2}{|c|}{ Weekly Hours Last Year } \\
\hline & OLS & $\begin{array}{c}\text { Final IV } \\
\text { Model }\end{array}$ & OLS & $\begin{array}{c}\text { Final IV } \\
\text { Model }\end{array}$ & OLS & $\begin{array}{c}\text { Final IV } \\
\text { Model }\end{array}$ \\
\hline $\begin{array}{l}\text { Employment } \\
\text { Access }\end{array}$ & $\begin{array}{l}0.006 \\
(0.32)\end{array}$ & $\begin{array}{l}0.308 \\
(2.02)\end{array}$ & $\begin{array}{l}1.769 \\
(2.83)\end{array}$ & $\begin{array}{l}19.156 \\
(3.41)\end{array}$ & $\begin{array}{l}-1.501 \\
(2.68)\end{array}$ & $\begin{array}{l}36.068 \\
(7.42)\end{array}$ \\
\hline Percent Poverty & $\begin{array}{r}-0.528 \\
(20.62)\end{array}$ & $\begin{array}{l}-1.055 \\
(8.29)\end{array}$ & $\begin{array}{l}-11.176 \\
(15.03)\end{array}$ & $\begin{array}{c}-14.709 \\
(3.18) \\
\end{array}$ & $\begin{array}{l}-3.550 \\
(5.14) \\
\end{array}$ & $\begin{array}{l}6.027 \\
(1.52) \\
\end{array}$ \\
\hline $\begin{array}{l}\text { Percent College } \\
\text { Graduate }\end{array}$ & $\begin{array}{l}-0.099 \\
(15.01\end{array}$ & $\begin{array}{l}-0.434 \\
(9.71)\end{array}$ & $\begin{array}{r}-2.397 \\
(12.26) \\
\end{array}$ & $\begin{array}{c}-13.929 \\
(8.62) \\
\end{array}$ & $\begin{array}{l}1.264 \\
(6.11)\end{array}$ & $\begin{array}{l}-17.186 \\
(11.93)\end{array}$ \\
\hline $\begin{array}{l}\text { Housing Price } \\
\text { Residual }\end{array}$ & & $\begin{array}{l}0.514 \\
(9.48)\end{array}$ & & $\begin{array}{l}7.270 \\
(3.76) \\
\end{array}$ & & $\begin{array}{l}11.685 \\
(7.33)\end{array}$ \\
\hline \multicolumn{7}{|c|}{ Supplemental Labor Market Outcomes } \\
\hline & \multicolumn{2}{|c|}{ Worked Last Year } & \multicolumn{2}{|c|}{ Employment Last Week } & \multicolumn{2}{|c|}{ Hours Worked Last Week } \\
\hline & OLS & $\begin{array}{c}\text { Final IV } \\
\text { Model }\end{array}$ & OLS & $\begin{array}{c}\text { Final IV } \\
\text { Model }\end{array}$ & OLS & $\begin{array}{c}\text { Final IV } \\
\text { Model }\end{array}$ \\
\hline $\begin{array}{l}\text { Employment } \\
\text { Access }\end{array}$ & $\begin{array}{c}-0.004 \\
(0.25) \\
\end{array}$ & $\begin{array}{l}0.647 \\
(3.98) \\
\end{array}$ & $\begin{array}{l}0.013 \\
(1.17) \\
\end{array}$ & $\begin{array}{l}0.362 \\
(3.10) \\
\end{array}$ & $\begin{array}{c}-1.324 \\
(2.20) \\
\end{array}$ & $\begin{array}{l}44.266 \\
(8.34)\end{array}$ \\
\hline Percent Poverty & $\begin{array}{r}-0.661 \\
(24.91) \\
\end{array}$ & $\begin{array}{l}-1.308 \\
(9.46) \\
\end{array}$ & $\begin{array}{l}-0.146 \\
(9.14) \\
\end{array}$ & $\begin{array}{l}-0.337 \\
(3.32) \\
\end{array}$ & $\begin{array}{l}-4.498 \\
(5.86) \\
\end{array}$ & $\begin{array}{l}1.906 \\
(0.42) \\
\end{array}$ \\
\hline $\begin{array}{l}\text { Percent College } \\
\text { Graduate }\end{array}$ & $\begin{array}{r}-0.067 \\
(10.45) \\
\end{array}$ & $\begin{array}{r}-0.603 \\
(12.59) \\
\end{array}$ & $\begin{array}{l}0.009 \\
(2.63)\end{array}$ & $\begin{array}{l}-0.258 \\
(7.96) \\
\end{array}$ & $\begin{array}{l}0.646 \\
(2.89) \\
\end{array}$ & $\begin{array}{l}-19.296 \\
(12.25) \\
\end{array}$ \\
\hline $\begin{array}{l}\text { Housing Price } \\
\text { Residual }\end{array}$ & & $\begin{array}{r}0.704 \\
(11.70)\end{array}$ & & $\begin{array}{l}0.201 \\
(4.92)\end{array}$ & & $\begin{array}{l}12.920 \\
(7.27)\end{array}$ \\
\hline
\end{tabular}

Notes: The first panel presents the core results from Table 2 while the second panel presents results based on the following alternative dependent variables: whether worked at all last year, whether employed last week conditional on labor force participation, and average hours worked last week conditional on being employed. The first, third and fifth columns contain OLS estimates with standard errors clustered at the census block group. The second, fourth, and sixth columns contain estimates for the multi-stage instrumental variables analysis with standard errors clustered at the cell. T-statistics are shown in parentheses. 


\begin{tabular}{|c|c|c|c|c|c|c|}
\hline \multirow[t]{2}{*}{ Variables } & \multicolumn{2}{|c|}{ Labor Force Participant } & \multicolumn{2}{|c|}{ Weeks Worked Last Year } & \multicolumn{2}{|c|}{$\begin{array}{c}\text { Average Hours per Week } \\
\text { Last Year }\end{array}$} \\
\hline & $\begin{array}{c}\text { Final IV } \\
\text { Model }\end{array}$ & $\begin{array}{c}\text { Control for } \\
\text { Housing } \\
\text { Stock } \\
\end{array}$ & $\begin{array}{c}\text { Final IV } \\
\text { Model }\end{array}$ & $\begin{array}{c}\text { Control for } \\
\text { Housing } \\
\text { Stock } \\
\end{array}$ & $\begin{array}{c}\text { Final IV } \\
\text { Model }\end{array}$ & $\begin{array}{c}\text { Control for } \\
\text { Housing } \\
\text { Stock } \\
\end{array}$ \\
\hline $\begin{array}{l}\text { Employment } \\
\text { Access }\end{array}$ & $\begin{array}{l}0.308 \\
(2.02)\end{array}$ & $\begin{array}{l}0.591 \\
(3.84)\end{array}$ & $\begin{array}{l}19.156 \\
(3.41)\end{array}$ & $\begin{array}{c}20.941 \\
(3.68)\end{array}$ & $\begin{array}{l}36.068 \\
(7.42)\end{array}$ & $\begin{array}{l}38.235 \\
(7.70)\end{array}$ \\
\hline Percent Poverty & $\begin{array}{r}-1.055 \\
(8.29) \\
\end{array}$ & $\begin{array}{l}-1.079 \\
(8.60) \\
\end{array}$ & $\begin{array}{c}-14.709 \\
(3.18) \\
\end{array}$ & $\begin{array}{c}-14.580 \\
(3.18) \\
\end{array}$ & $\begin{array}{l}6.027 \\
(1.52) \\
\end{array}$ & $\begin{array}{l}5.862 \\
(1.49) \\
\end{array}$ \\
\hline $\begin{array}{l}\text { Percent College } \\
\text { Graduate }\end{array}$ & $\begin{array}{l}-0.434 \\
(9.71)\end{array}$ & $\begin{array}{r}-0.633 \\
(12.36)\end{array}$ & $\begin{array}{c}-13.929 \\
(8.62)\end{array}$ & $\begin{array}{c}-15.650 \\
(8.97)\end{array}$ & $\begin{array}{l}-17.186 \\
(11.93)\end{array}$ & $\begin{array}{l}-19.122 \\
(11.92)\end{array}$ \\
\hline $\begin{array}{l}\text { Housing Stock } \\
\text { Index }\end{array}$ & & $\begin{array}{c}0.622 \\
(10.21)\end{array}$ & & $\begin{array}{l}4.350 \\
(2.25)\end{array}$ & & $\begin{array}{l}5.021 \\
(2.58)\end{array}$ \\
\hline $\begin{array}{l}\text { Housing Price } \\
\text { Residual }\end{array}$ & $\begin{array}{l}0.514 \\
(9.48)\end{array}$ & $\begin{array}{r}0.595 \\
(11.43)\end{array}$ & $\begin{array}{l}7.270 \\
(3.76)\end{array}$ & $\begin{array}{l}8.277 \\
(4.48)\end{array}$ & $\begin{array}{l}11.685 \\
(7.33)\end{array}$ & $\begin{array}{l}12.564 \\
(8.14)\end{array}$ \\
\hline
\end{tabular}

Notes: The first, third and fifth columns contain estimates from our standard multi-stage instrumental variables analysis, and the second, fourth, and sixth columns contain estimates for models that also include a housing stock quality index based on the same housing stock variables used to instrument for the neighborhood composition variables and the coefficients estimated on those variables in the housing price hedonic. The model includes the actual housing stock variable rather than an instrument based on the exposure of cells of observationally equivalent households in order to control for neighborhood unobservables that might correlate with housing stock. T-statistics are shown in parentheses. 